\title{
How does chemotherapy treatment damage the prepubertal testis?
}

\author{
Caroline M Allen ${ }^{1}$, Federica Lopes ${ }^{1}$, Rod T Mitchell ${ }^{2}$ and Norah Spears ${ }^{1}$ \\ ${ }^{1}$ Biomedical Sciences, University of Edinburgh, Edinburgh, UK and ${ }^{2}$ MRC Centre for Reproductive Health, \\ University of Edinburgh, Edinburgh, UK \\ Correspondence should be addressed to N Spears; Email: norah.spears@ed.ac.uk
}

\begin{abstract}
Chemotherapy treatment is a mainstay of anticancer regimens, significantly contributing to the recent increase in childhood cancer survival rates. Conventional cancer therapy targets not only malignant but also healthy cells resulting in side effects including infertility. For prepubertal boys, there are currently no fertility preservation strategies in use, although several potential methods are under investigation. Most of the current knowledge in relation to prepubertal gonadotoxicity has been deduced from adult studies; however, the prepubertal testis is relatively quiescent in comparison to the adult. This review provides an overview of research to date in humans and animals describing chemotherapy-induced prepubertal gonadotoxicity, focusing on direct gonadal damage. Testicular damage is dependent upon the agent, dosage, administration schedule and age/pubertal status at time of treatment. The chemotherapy agents investigated so far target the germ cell population activating apoptotic pathways and may also impair Sertoli cell function. Due to use of combined chemotherapy agents for patients, the impact of individual drugs is hard to define, however, use of in vivo and in vitro animal models can overcome this problem. Furthering our understanding of how chemotherapy agents target the prepubertal testis will provide clarity to patients on the gonadotoxicity of different drugs and aid in the development of cytoprotective agents.

Reproduction (2018) 156 R209-R233
\end{abstract}

\section{Introduction}

The overall childhood cancer survival rate has increased substantially in recent decades, with the current 5-year survival rate at around $80 \%$, compared to about $58 \%$ in the late 1970s (Miller et al. 2016). This marked advance, due in large part to improved chemotherapy treatments, has led to a growing population of long-term childhood cancer survivors. However, chemotherapy drugs do not exclusively target malignant cells, also eliciting side effects due to off-target damage to healthy tissues. Given this situation, research is increasingly focusing on preventing damage to healthy organs, to improve the quality of life for childhood cancer survivors. For younger patients, detrimental effects of treatment on fertility can be a major concern (Zebrack et al. 2004). This is particularly problematic for male survivors of childhood cancer, given the current lack of available fertility preservation treatments, since, unlike adult patients, these prepubertal patients do not yet produce mature spermatozoa that can be used for routine sperm cryopreservation (Wyns et al. 2010, Wallace 2011, Mitchell et al. 2017). Recently, centres have started to cryopreserve immature testicular tissue from prepubertal boys before the commencement of chemotherapy treatment. In 2015, there were seven centres in Europe collecting such tissues with more than 260 prepubertal samples stored, with biopsies undertaken only when treatment is deemed at high risk for later fertility complications (Picton et al. 2015, Mitchell et al. 2017). At this point, however, it is not yet certain if such cryopreserved tissue can be successfully used later to restore fertility in humans, as production of viable sperm from such tissue is yet to be shown. A recent report has described the generation of sperm-like cells after 3D culture of isolated spermatogonial cells obtained from testis biopsies taken from prepubertal boys undergoing chemotherapy treatment (Abofoul-Azab et al. 2018). This is encouraging for the future, but in this preliminary study, the technique was successful in only one out of six patient biopsies, and the functionality of the sperm-like cells remains to be established. Research in animal models has been more successful in showing the potential of fertility preservation techniques, which could be developed for clinical use (reviewed in Picton et al. 2015, Giudice et al. 2017). Transplantation of spermatogonial stem cells (SSCs) or frozen-thawed immature testicular tissue grafted back into the adult has been successful in producing functional gametes in animal models including the non-human primate and murine (Brinster \& Zimmermann 1994, Mitchell et al. 2010, Hermann et al. 2012, Jahnukainen et al. 2012). 
Healthy offspring have been produced through IVF/ ICSI using sperm derived from xenografted non-human primate immature testicular tissue demonstrating the potential of this technique for clinical application (Liu et al. 2016). There are concerns, however, for non-solid tumours that malignant cells could be reintroduced back into the patient, particularly with tissue transplantation as shown in the Hou et al. (2007) study where leukaemic infiltration was noted within the xenografted testicular tissue. In addition to in vivo techniques, sperm has been grown in culture from immature testis through in vitro spermatogenesis, and these sperm have been used for IVF/ICSI to produce viable embryos in a mouse model system (Sato et al. 2011). There have also been recent reports of in vitro culture of human prepubertal testicular tissue, although without completion of spermatogenesis (de Michele et al. 2017, 2018). For all such potential fertility preservation techniques, further research is needed to allow the methods to be successfully transformed for use with human tissue, after which further validation will be required to ensure that such methodologies are efficient and safe for clinical use. An alternative strategy, rather than the subsequent restoration of fertility after chemotherapy-induced infertility, would be the development of interventions administered before and/or during chemotherapy treatment to prevent the damage from occurring in the first instance, thus protecting the fertility potential of the patient. Cytoprotective agents that specifically protect the prepubertal testis against chemotherapyinduced damage, without interfering with the toxicity to cancer cells, could potentially be employed as part of the chemotherapy treatment regimen. However, further research is required to fully understand how chemotherapy drugs target the prepubertal testis and which compounds could potentially prevent such damage.

This review provides an overview of research to date that has focused upon the direct, chemotherapy druginduced damage to the prepubertal testis: such studies often rely on histological analysis. Damage can also be conferred from studies examining hormonal changes after cancer treatment. For example, $\mathrm{AMH}$ and inhibin $B$ can be used as markers of Sertoli cell function, although the use of such markers during prepuberty is yet to be investigated (Dere et al. 2013, Stukenborg et al. 2018a). The use of hormonal indicators to determine chemotherapy-induced damage is not discussed further in this review. The review discusses papers only where they investigate effects on the prepubertal testicular tissue/cells, either from human or animal models. Determining which cell types within the prepubertal testis are directly targeted by chemotherapy drugs, along with the potential mechanism of action of the different drugs, will provide vital information enhancing our knowledge on the gonadotoxicity of chemotherapy agents and the development of cytoprotective agents against chemotherapy-induced damage.

\section{Methodology}

A literature search was conducted to identify relevant papers to query our research question; how does chemotherapy treatment damage the prepubertal testis? A review of the literature was performed using PRISMA guidelines (Moher et al. 2009). Relevant papers were identified using PubMed to search for appropriate references, searching key words including prepubertal/ immature, testes, chemotherapy (including classes of drugs) and fertility preservation. Additional references were found by searching reference lists of such papers. The abstracts of identified papers were screened for relevance in relation to chemotherapy treatment during prepuberty and impact on the testis. The eligibility of relevant studies was assessed by reading the screened papers in full to ensure that all those included in this review are all concerning prepubertal tissues, whether from human patients or animal models. Clinical studies are included where the histology of the testis of human patients following prepubertal cancer treatment is examined during or at the end of the treatment period or during adulthood. In vivo studies in animal models where drug exposure occurred prior to the onset of puberty as well as in vitro studies of cultured cells and tissues obtained from prepubertal animals were also analysed. Potential fertility cytoprotectants were included where research was performed on prepubertal/ immature subjects. Of the papers that were excluded, the majority were due to chemotherapy treatment taking place during/after puberty, analysis of chemotherapyinduced damage through hormonal changes or failure to report the dose of the chemotherapy agents. Overview of our research strategy is shown in Fig. 1.

\section{Childhood cancer and treatment}

\section{Incidence of childhood cancer}

Each year around 1800 children are diagnosed with neoplastic disease, accounting for $1 \%$ of new cancer diagnoses in the United Kingdom (Wallace 2011, Cancer Research UK 2015). Cancer is the second most common cause of death in children. The nature of cancers that develop at this young age differs from those of adult malignant tumours. In infants, tumours of embryonal origin such as neuroblastomas are the most frequent cause, whereas in older children, leukaemia (particularly acute lymphoblastic leukaemia) as well as central nervous system tumours and lymphomas (nonHodgkins and Hodgkins) are more often diagnosed. There is also a sex difference in incidence, with boys 1.2 times more likely to be diagnosed with cancer, 


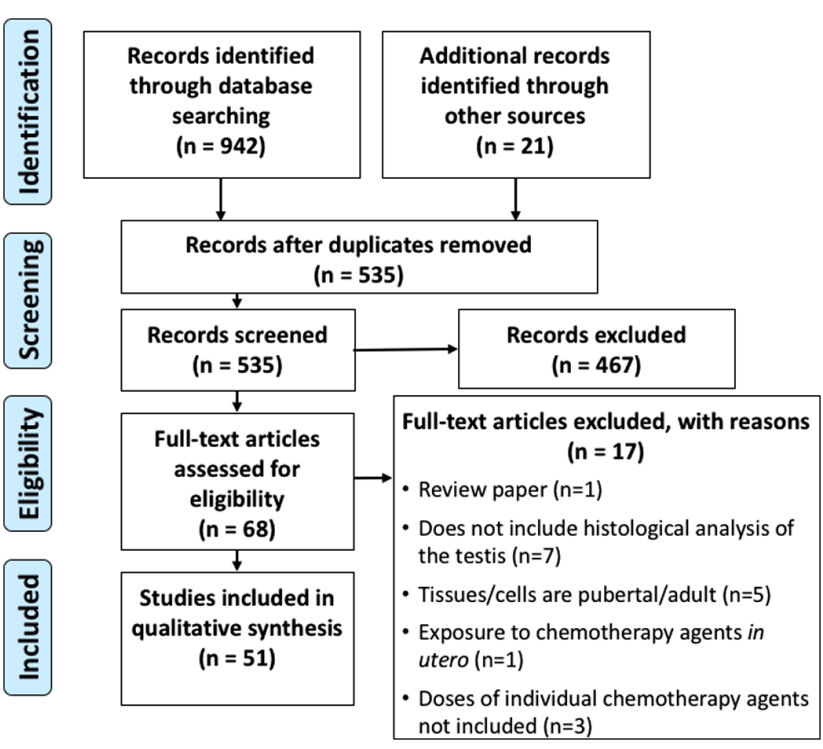

Figure 1 PRISMA flow diagram of literature search. PRISMA flow diagram of search results, study screening, and study inclusion, following a review of the literature carried out using PRISMA guidelines (Moher et al. 2009).

particularly lymphomas and central nervous system tumours (Kaatsch 2010, Kelly 2017).

\section{Chemotherapy treatment}

Chemotherapy and radiotherapy are a mainstay of treatment for childhood malignancies. For chemotherapy drugs, the refinement and use of combined drug treatments have contributed greatly to the dramatic increase in childhood cancer survival rates over recent decades (Anderson et al. 2015, Miller et al. 2016). Multiple different drugs have been established in treatment regimens; these kill cancer cells through various mechanisms, often targeting proliferating cells (Table 1) (Malhotra \& Perry 2003, Lind 2011). The gonadotoxic impact and relative risk of later infertility of individual chemotherapy agents included in treatment regimens against childhood malignancies can at present only be estimated, since the risk is dependent on multiple factors including dosage, treatment length, age at time of treatment and the sensitivity of individual patients to chemotherapy treatment. The current classification of chemotherapy drugs and the dosages considered to result in infertility are outlined in Table 1; however, these classifications/dosages are debated. Given that clinicians use this knowledge to determine whether or not to offer cryopreservation of testicular tissue before commencement of treatment, further elucidation on relative risk/gonadotoxicity is urgently required. At present, alkylating and alkylating-like agents such as cyclophosphamide and cisplatin are considered to be highly gonadotoxic with these agents intercalating into DNA, disrupting basic cellular processes. These agents are commonly included in treatment regimens to treat a wide range of childhood malignancies and are known to result in subsequent infertility in adulthood (Chow et al. 2016). Agents from alternative drug classes which have different mechanisms of action are considered low or moderate risk of later infertility and include; antimetabolites such as cytarabine, vinca alkaloids e.g. vincristine and topoisomerase inhibitors including etoposide. There are also some chemotherapy agents, including taxanes, where infertility risk/gonadotoxicity is at present unknown. Further details are included in Table 1.

For the vast majority of paediatric cancers, combined chemotherapy with multiple agents is required to effectively treat the disease, with commonly used combinations including MOPP (nitrogen mustard, vincristine, procarbazine and prednisolone) or ABVD (doxorubicin, bleomycin, vinblastine and dacarbazine) for treatment of Hodgkins lymphoma and $\mathrm{CHOP}$ (cyclophosphamide, doxorubicin, vincristine and prednisolone) for non-Hodgkins lymphoma (Corrie 2011). The administration of several agents in a treatment regimen could potentially result in additive or even multiplicative side effects on healthy tissues.

\section{Testis development}

The testis is responsible for producing mature spermatozoa along with the main male reproductive hormone, testosterone. During prepuberty, the testis was originally thought to be relatively inactive based on studies demonstrating few morphological changes and a lack of hormone production during this period (Rey 1999). However, further detailed analysis has shown that the prepubertal testis undergoes important developmental processes, which are required for normal adult functioning (Fig. 2A). This section will outline what is currently known regarding testis development, focusing primarily upon human development. Many studies, however, have relied upon animal models to observe prepubertal changes due to the challenges of studying the human testis; information about nonhuman species will be specified where relevant.

\section{Foetal life}

The testis forms during early foetal life from an undifferentiated bipotential gonad. The primordial germ cells, originally located outside the embryo within the yolk sac, migrate and populate the gonadal ridge (Stukenborg et al. 2014). Under the action of the $S R Y$ (sex-determining region $Y$ ) gene, which drives production of the SOX9 (SRY-box 9) protein, Sertoli cells differentiate from precursors cells within the gonadal ridge and engulf the primordial germ cells which are now classified as gonocytes. This configuration results in the formation of seminiferous cords, which predominantly 


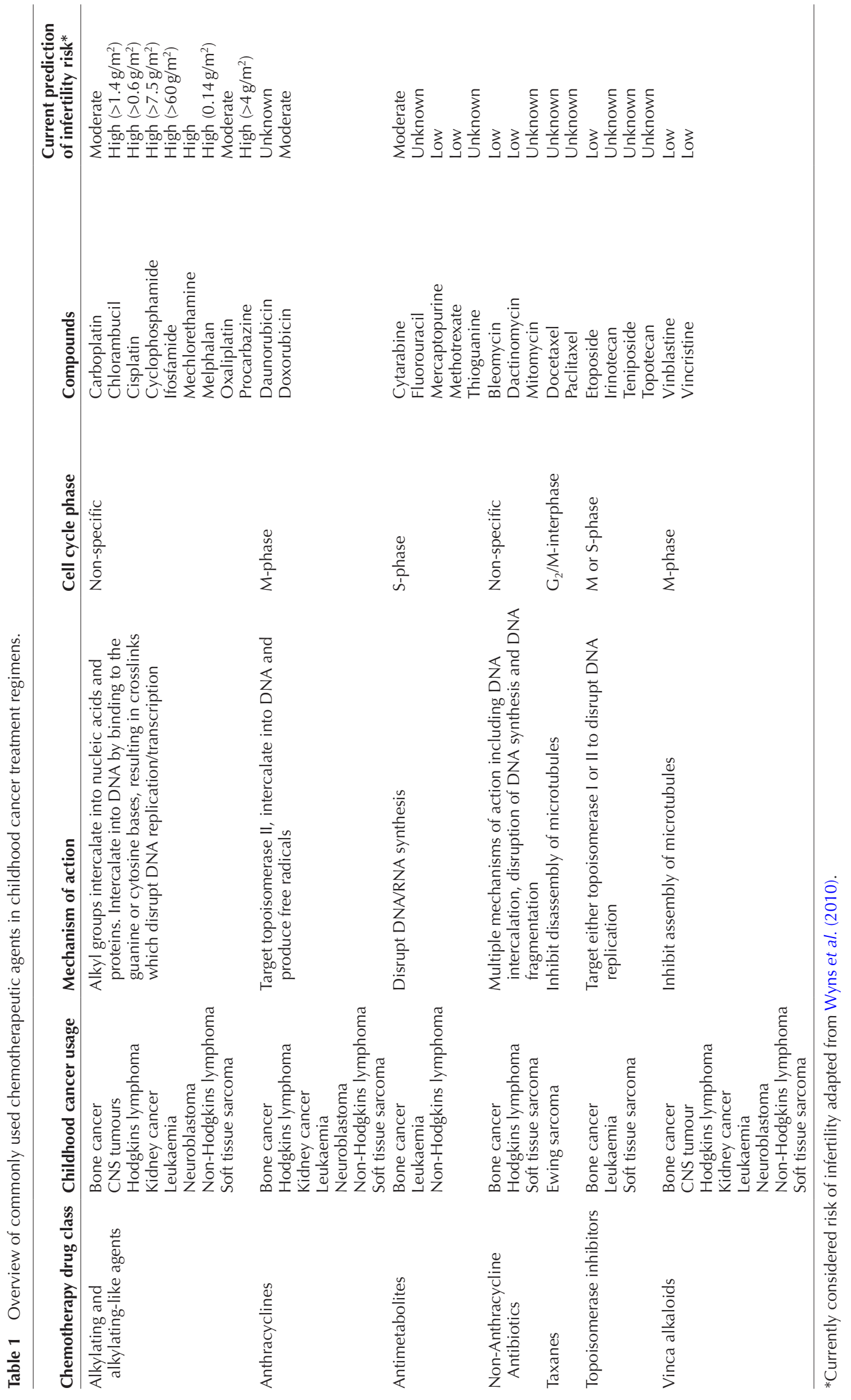


A

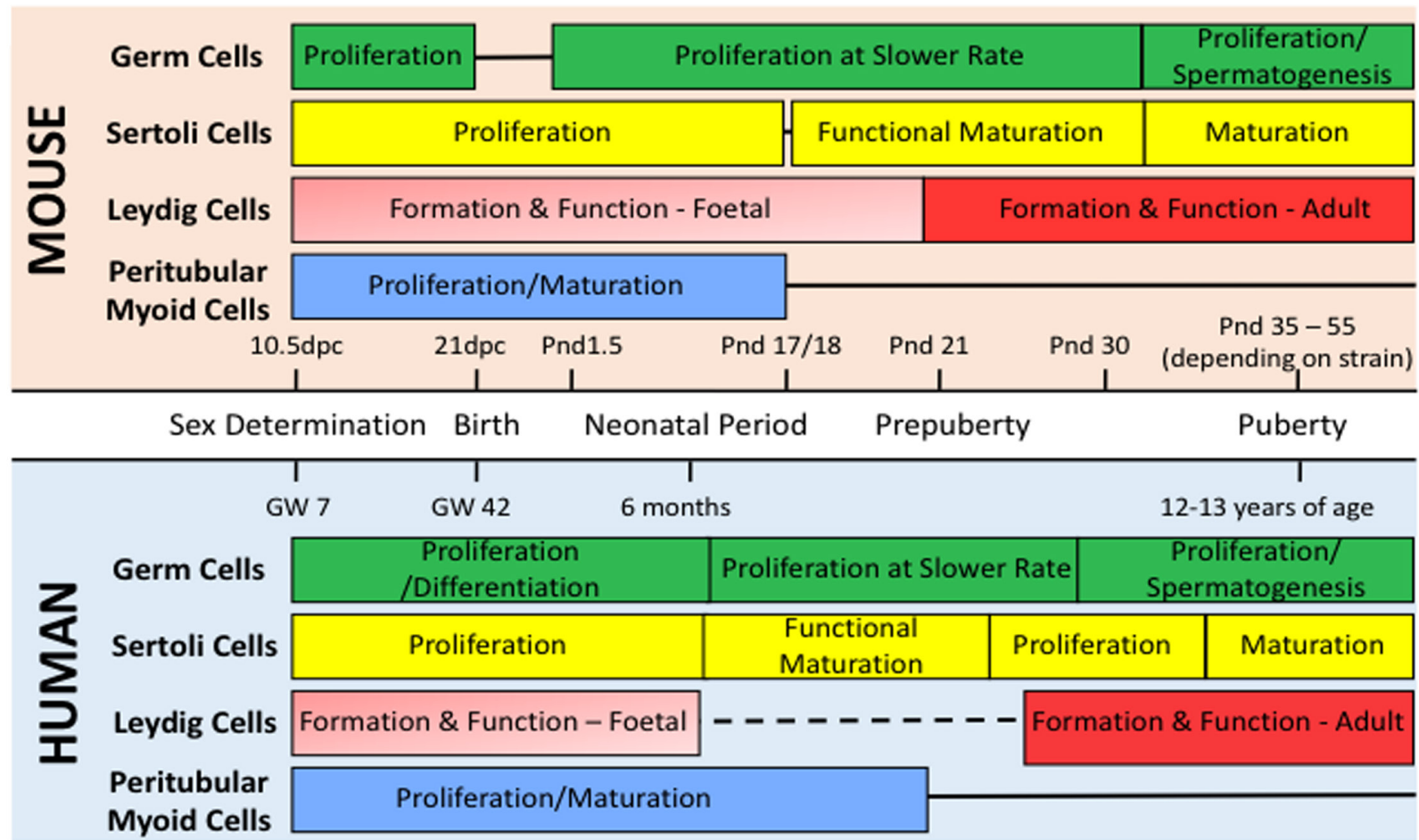

B

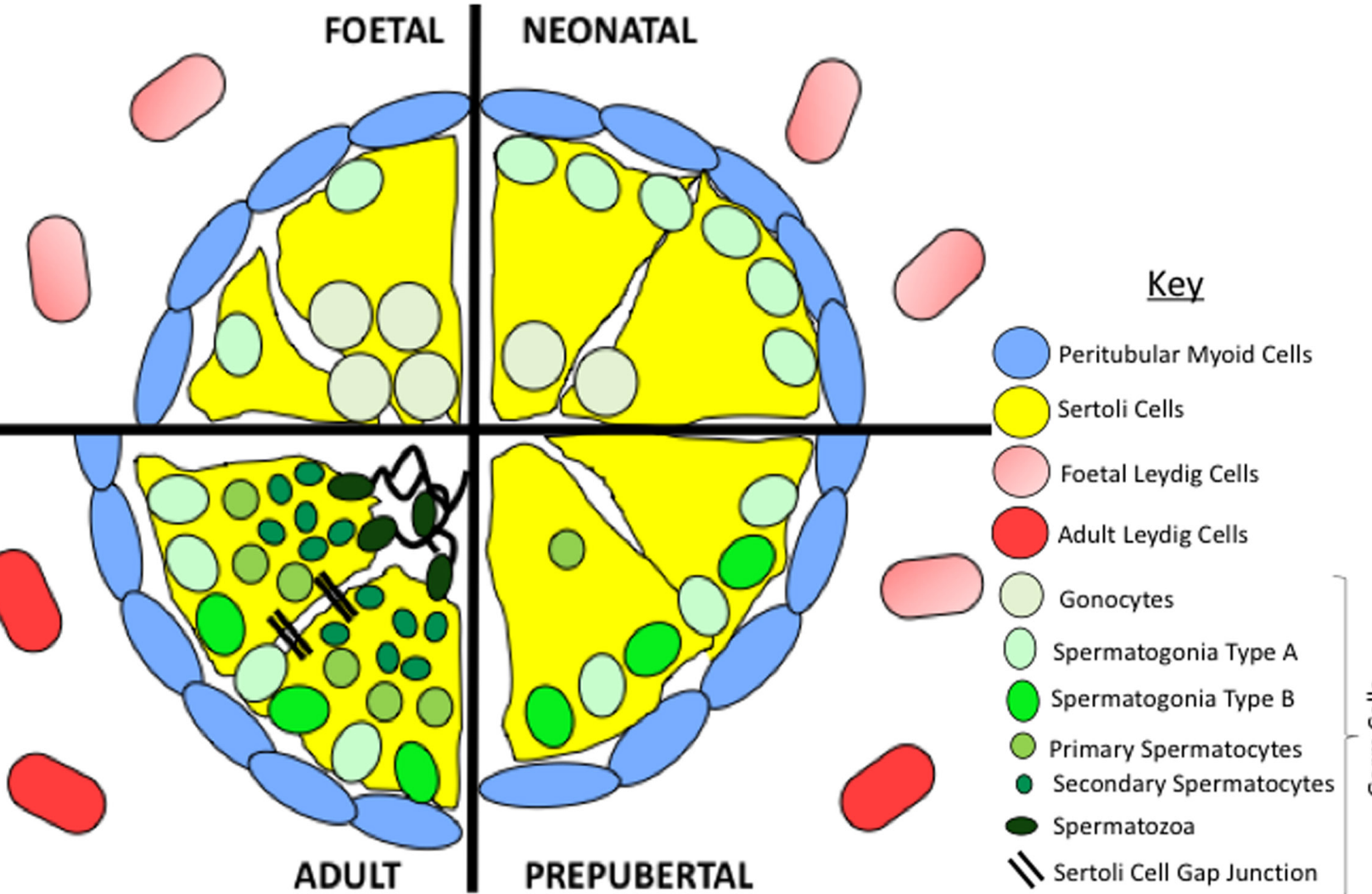

Figure 2 Comparison of testicular development in humans and rodents. (A) Relative timeframe of important developmental processes taking place between foetal development and puberty in humans (Chemes 2001) and the mouse model (Vergouwen et al. 1993). Solid line indicates no activity of the cells at the relevant time points and dashed line represents the unknown nature of Leydig cell development during this timeframe. (B) Comparison of the histology of the testis throughout development in the human, from foetal development through to the adult testis. dpc, days post coitum; GW, gestational week; pnd, postnatal day. 
contain Sertoli cells with centrally located gonocytes. The Sertoli cells are key drivers in the differentiation and function of other cellular components of the testis including the Leydig cells and peritubular myoid cells (reviewed in Svingen \& Koopman 2013) (Fig. 2B). The hypothalamic-pituitary-gonadal axis (HPG) is active during foetal life, producing the gonadotrophins folliclestimulating hormone (FSH) and luteinizing hormone, which are essential for the formation, maturation and function of key somatic cells including the Sertoli and Leydig cells (Stukenborg et al. 2018a).

During foetal development, the gonocytes actively proliferate into early neonatal life, and differentiation of the gonocytes into pre-spermatogonia occurs asynchronously during foetal and early postnatal life, with the gonocytes having greater proliferative activity than the pre-spermatogonia. In the rodent model, however, the proliferation of the gonocytes ceases during late foetal life and resumes during the early postnatal period (Ferrara et al. 2006, Mitchell et al. 2008, Wu et al. 2009). Sertoli cells actively proliferate during foetal development under the control of multiple hormones, particularly $\mathrm{FSH}$. This period of proliferation is very important in determining adult numbers of Sertoli cells (Sharpe et al. 2003). Peritubular myoid cells develop from interstitial cells, when multiple layers of these cells along with extracellular matrix proteins surround and form the wall of the seminiferous cords. These cells contribute to the basement membrane providing structural support during testis development and will function in the adult to aid movement of mature sperm towards the lumen (Mayerhofer 2013, Svingen \& Koopman 2013). The endocrine somatic Leydig cells are situated within the interstitial compartment between seminiferous cords and are composed of different cell populations throughout an individual's lifespan. The foetal Leydig cells (FLCs) produce testosterone throughout foetal life, which is essential for masculinization of the male reproductive system. These cells ultimately regress after birth and are replaced by adult Leydig cells (ALCs) during puberty (Habert et al. 2001, Chen et al. 2009, Svechnikov et al. 2010), however, the presence and/or function of the FLCs have recently been shown to be important in the formation and function of the ALCs in a rodent model (Su et al. 2018). Whether FLCs and ALCs are distinct populations of cells or share a common stem/progenitor cell lineage is at present unknown; however, stem ALCs have been observed in the human foetal testis (Kilcoyne et al. 2014, Teerds \& Huhtaniemi 2015).

\section{Neonatal life}

During the first 3 months of neonatal life, the reproductive system undergoes a short period of activity known as 'mini-puberty', where the HPG axis is active (Kuiri-Hänninen et al. 2014). The origin of the Leydig cells that produce testosterone during 'mini-puberty' is unknown, possibly forming from precursor cells or from the FLCs (Svechnikov et al. 2010). The function of 'minipuberty' is yet to be clarified, but is thought to be linked to later reproductive function in the adult (Copeland \& Chernausek 2016). This short neonatal activity has also been observed in the primate animal model during neonatal development but does not appear to occur in rodents, where infancy overlaps with early stages of pubertal development (Chemes 2001, Kelnar 2002).

The volume of the testis increases six-fold during neonatal development due to proliferation of Sertoli cells stimulated by FSH secretion; $93-95 \%$ of the seminiferous cord mass is attributed to the Sertoli cells at this stage (Müller \& Skakkebaek 1983, Rey et al. 1993; reviewed in Petersen \& Söder 2006). This increase in cell number results in an overall increase in seminiferous cord length but not diameter, as each Sertoli cell maintains contact with the basement membrane, the cells spreading lengthwise (Chemes 2001). Therefore, in a cross-sectional area of the seminiferous cord, it may appear as though the cell density remains stable or even decreases during this period of development, which can be misleading. The resulting number of Sertoli cells will ultimately determine sperm production in the adult, with each Sertoli cell able to support a species-specific number of germ cells (Sharpe 2001).

During the foetal and early postnatal period of development, centrally located gonocytes within the seminiferous cords differentiate and lose their pluripotency. At around 2-3 months of age, the differentiating cells migrate towards the basement membrane, developing into the SSCs (Culty 2009). The SSCs are now located within the stem cell niche in the basal compartment of the seminiferous cords, outside of the blood-testis barrier (BTB), which will later form during puberty to protect post-meiotic germ cells (Stanton 2016, Li et al. 2017). The maintenance of the SSC niche is dependent on factors produced by somatic cells (Stukenborg et al. 2018a). In rodents, there is a relatively rapid and synchronous differentiation of gonocytes to pre-spermatogonia and migration to the basal membrane occurring by postnatal day (pnd) six (Mitchell et al. 2008, Wu et al. 2009).

\section{Prepuberty}

Prepuberty lasts for around 11 years until the HPG axis is once again reactivated and the child enters puberty. During prepuberty, perceived reduced cellular activity in the testis was thought to confer protection against insult (Rivkees \& Crawford 1988) (Fig. 2A). However, this does not appear to be the case as shown in studies demonstrating infertility in adults following childhood chemotherapy treatment (Chow et al. 2016).

During prepuberty, the proliferative rate of the germ cell population is reduced in comparison with foetal development; nevertheless, there is a three-fold 
increase in the overall germ cell population during this time period (Müller \& Skakkebaek 1983). At this point, the SSC pool is represented by undifferentiated A spermatogonia composed of two populations of cells with a dark $\left(A_{\text {dark }}\right)$ or pale $\left(A_{\text {pale }}\right)$ appearance. $A_{\text {dark }}$ spermatogonia are believed to represent the reserve stem cells with low mitotic activity, whilst the $A_{\text {pale }}$ cells are actively proliferating. Upon differentiation, the $A_{\text {pale }}$ spermatogonia differentiate to B spermatogonia, which can be observed from 4 to 5 years of age (Paniagua \& Nistal 1984). Type B spermatogonia will enter meiosis to form spermatozoa in the adult (Ehmcke et al. 2006, Stukenborg et al. 2014). In rodents, $A_{\text {single }}\left(A_{s}\right)$ spermatogonia actively proliferate to form two conjoined daughter cells known as $A_{\text {paired }}\left(A_{p r}\right)$ cells which continuously divide forming $A_{\text {aligned }}\left(A_{a l}\right)$ chains (reviewed in de Rooij \& Russell 2000, Ehmcke et al. 2006). Occasionally, spermatogonia enter meiosis, leading to the infrequent observation of primary spermatocytes during prepuberty; however, these cells quickly degenerate since the somatic cells are not mature enough to support full spermatogenesis at this stage (Chemes 2001). The diameter of the tubules is unaltered during prepubertal development, with the lumen expanding only later during puberty due to intense germ cell proliferation that results in the expansion in tubule width (Chemes 2001). Reference values based upon a systematic review and meta-analysis performed by Masliukaite et al. (2016) indicates that spermatogonia number per tubular cross-section and density per area $\left(\mathrm{cm}^{3}\right)$ decrease during the first 3 years of life followed by a gradual increase up to 6 to 7 years of age, plateauing up to age 11 when boys begin to enter puberty and numbers increase dramatically. The initial decrease may be a result of programmed cell death of the gonocytes that failed to migrate to the basement membrane earlier in development (Masliukaite et al. 2016).

The Sertoli cells in the prepubertal testis appear morphologically immature, with little cytoplasm and with the nuclei arranged in palisade formation with small nucleoli (Chemes 2001). These somatic cells differentiate and undergo functional maturation during prepuberty, with increased expression of androgen receptors and connexin 43, as well as expression of vimentin and inhibin $\beta$ markers (Brehm et al. 2006, de Michele et al. 2018). In addition, Sertoli cells display aromatase activity and produce oestrogen during prepuberty (Chemes 2001). AMH, in particular, is secreted in large amounts in prepubertal boys and can be used as an indicator of Sertoli cell number and function; however, levels will decline during puberty and will be low throughout adulthood (Rey 1999). As in the foetus, Sertoli cell factors are involved in controlling the development/proliferation of other testicular cell types. The peritubular myoid cells proliferate and develop during early postnatal development in the rodent, under the control of FSH, with Sertoli cells having an important role in maintaining their differentiated state (Chemes 2001, Nurmio et al. 2012, Rebourcet et al. 2014). However, this dependency is lost when the peritubular myoid cells terminally differentiate during prepuberty, as shown in the rodent model (Rebourcet et al. 2014). These cells gain the ability to contract during puberty, with testosterone stimulating the expression of smooth muscle actin in the primate model (Mayerhofer 2013). The development of the Leydig cell population during the prepubertal period is less well understood with much of our knowledge based on rodent studies (Chen et al. 2009). In the rodent, Sertoli cells have an important role in stimulating ALC differentiation and will ultimately determine the number of ALCs in the adult (Rebourcet et al. 2014). The ALC population forms during puberty following reactivation of the HPG axis from stem/ progenitor cells, which proliferate during early postnatal life (Chen et al. 2009).

\section{Evidence of chemotherapy-induced direct damage to the prepubertal testis}

Understanding the specific mechanisms by which different classes of chemotherapy drugs directly target and damage the prepubertal testis is essential to aid development of protective strategies. Damage induced by chemotherapy treatment can have a major impact on the patient's reproductive outcome in later life, with impaired development of sexual characteristics and potential fertility consequences (Frederick et al. 2016). Long-term fertility depends on continued survival of male germ cells, specifically SSCs, and of functional supporting somatic cells (Zohni et al. 2012, Yoon et al. 2017, Stukenborg et al. 2018a). However, research focusing on direct damage to the testis is lacking within a clinical setting since testis tissue biopsy is not routinely performed before or after chemotherapy treatment. With recent focus on cryopreserving prepubertal testis samples before the onset of cytotoxic treatment for potential fertility preservation in the future, more tissue is becoming available for research and therefore studies using such tissue should be more common in the future. Indeed, a recent report by Stukenborg et al. (2018b) has histologically examined testis biopsies from prepubertal patients who were selected for cryopreservation of tissue due to the cytotoxic nature of their cancer treatment regimens. Research from animal studies has the potential to aid in understanding gonadal toxicity of individual drugs and their mechanism of action, as well as to examine the impact of clinically relevant combined treatments; however, to date, there have been few such studies. The human and animal studies discussed in this review focus on chemotherapy treatment delivered during the prepubertal period, where the damage can be assessed after treatment or implied from subsequent analysis of the adult testis. 


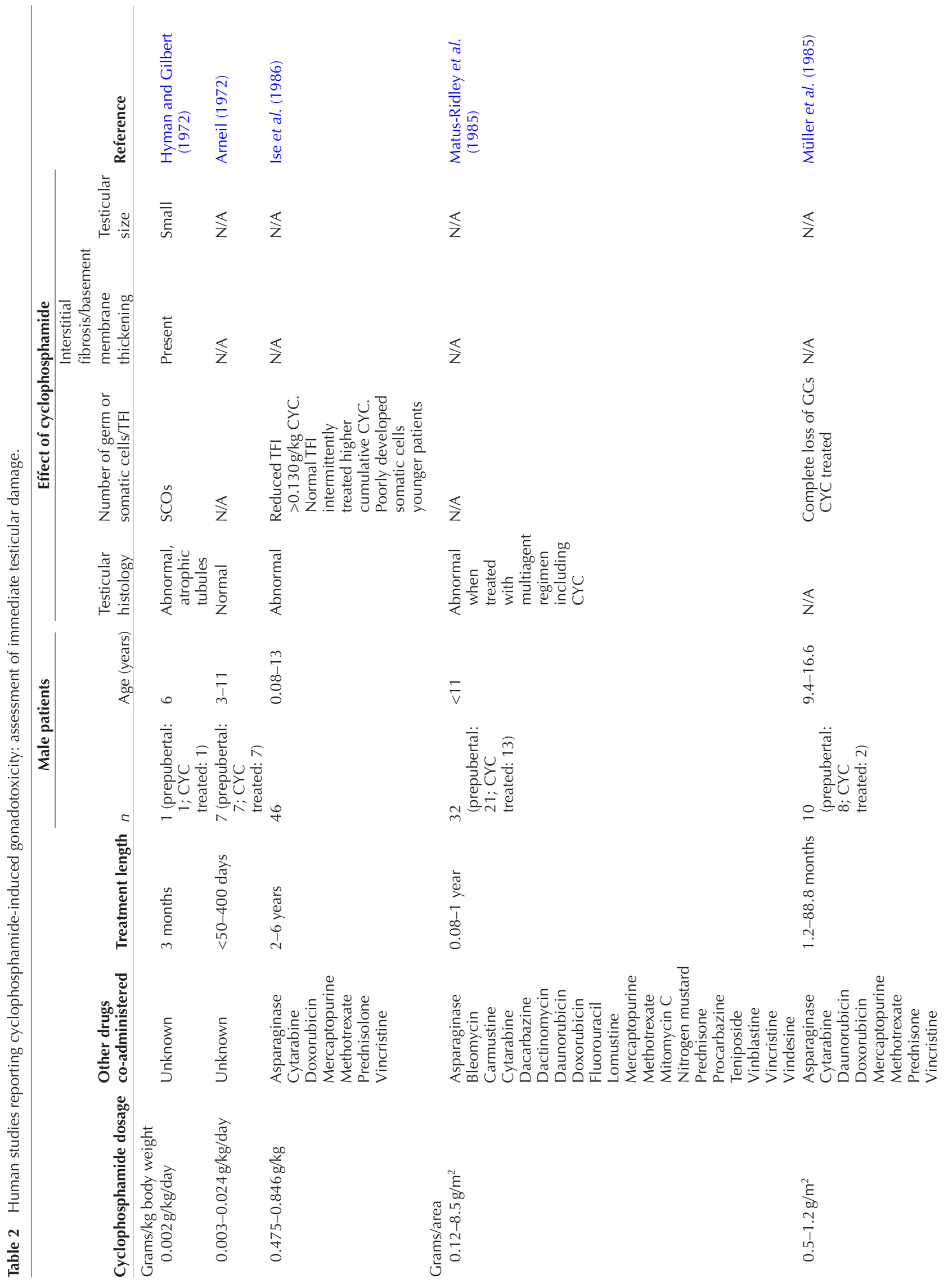




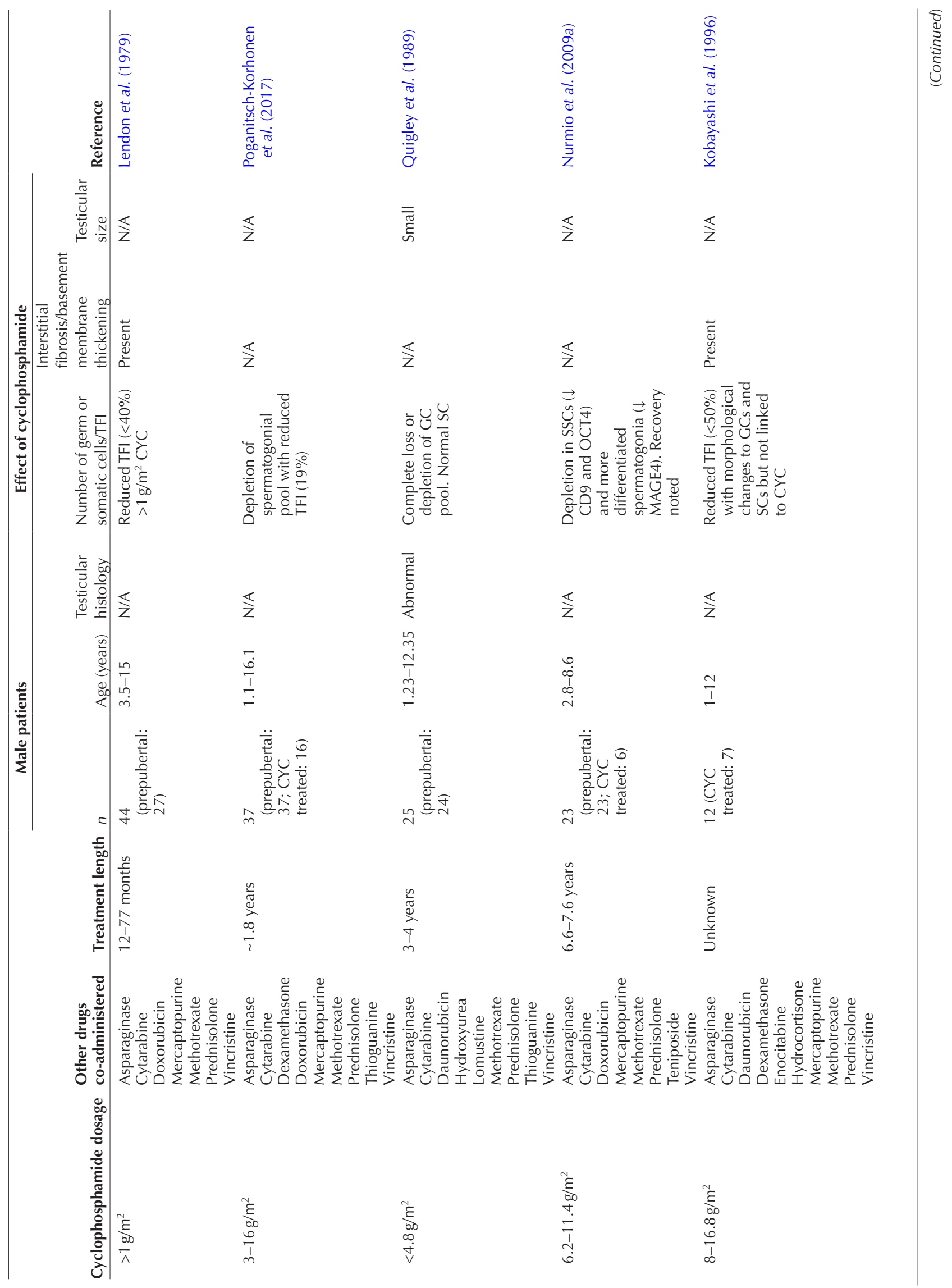




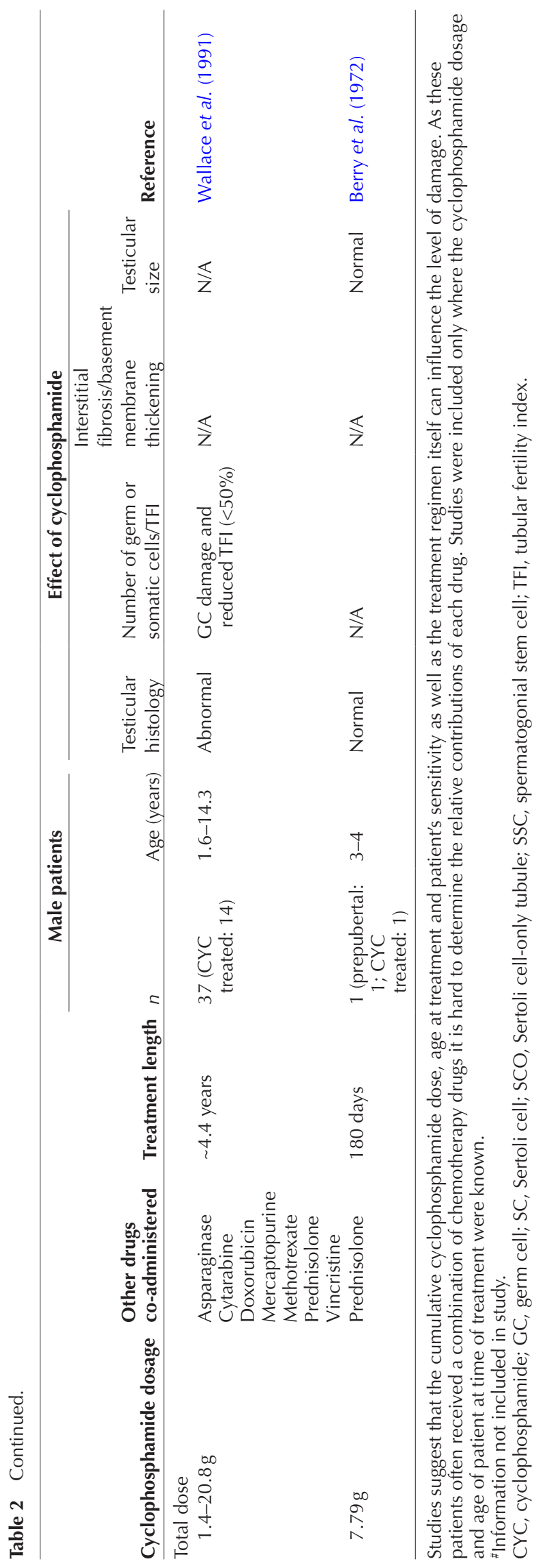

\section{Human studies}

Studies examining the direct testicular damage induced following chemotherapy treatment of prepubertal human patients are few and far between, with most of these linking the damage to cyclophosphamide treatment, although in almost all cases there is co-administration of other chemotherapy drugs (Table 2). Methods of analysis are descriptive in nature following histological analysis of testicular biopsies, for example, describing the general appearance of tubules and density of germ and somatic cells present. Additional analyses include calculation of the tubular fertility index, which represents the percentage of seminiferous tubules that contain spermatogonia (Ise et al. 1986). To the best of our knowledge, there are no papers where chemotherapy agents were tested for cytotoxicity through in vitro culture of testicular cells or tissues from human patients to include in this review. Many of the included studies present limitations such as small patient cohorts, lack of universal methods for defining pubertal status and lack of adequate control groups for comparison.

\section{Assessment of immediate testicular damage in prepubertal patients}

Following on from initial histological observations published in early case reports (Arneil 1972, Berry et al. 1972, Hyman \& Gilbert 1972), larger studies indicate a relationship between use of alkylating agents in treatment regimens and testicular tissue damage (Poganitsch-Korhonen et al. 2017, Stukenborg et al. 2018b). In particular, the inclusion of the drug cyclophosphamide for cancer treatment during the prepubertal period has been linked to resulting testicular damage (Table 2). The studies included here under 'immediate assessment' varied in the timeframe of analysis with the testicular damage examined at different time points including during, just before the cessation or at the end of the treatment period as well as up to a year after the end of treatment. These investigations have indicated that cyclophosphamide treatment is associated with testicular damage in a dose- and timedependent manner. Treatment can reduce the overall size of the testis where there is depletion of the germ cell population, resulting in Sertoli cell-only tubules, as well as interstitial fibrosis and basement membrane thickening (Hyman \& Gilbert 1972, Hensle et al. 1984, Uderzo et al. 1984). A cut-off dose at which such damage is evident is hard to define, since comparison between the few available studies is challenging due to the limitations previously described, as well as the variability of treatment regimens. The length of the treatment regimens may also determine the severity of the impairment, with higher cumulative doses over a shorter period of time reducing chemotherapy-induced damage (Ise et al. 1986). In many of the studies listed in 
Table 2 and discussed further in subsequent sections, only a subset of the patients exhibit severe damage to the testis following cyclophosphamide treatment. This indicates a degree of variability/susceptibility to damage which could be due to several factors, including age and genetic predisposition.

The testis itself is composed of somatic and germ cells, which could potentially each have different sensitivities to chemotherapeutic drugs. Damage to the somatic cells during chemotherapy treatment could negatively impact on the germ cells and vice versa (Stukenborg et al. 2018a). Nurmio et al. (2009a) have reported that cyclophosphamide targets both SSCs and more differentiated spermatogonia in the prepubertal testes, as indicated by changes in gene expression of specific spermatogonial markers (MAGE A4 and CD9). This is in agreement with most papers that reported effects on germ cells, with one study describing the appearance of immature Leydig and Sertoli cells following cyclophosphamide treatment (Ise et al. 1986).

Assessment of the effect of prepubertal drug exposure damage in the adult

Insult to the prepubertal testes following chemotherapy treatment can be inferred from examination of pubertal/ adult patients who were treated as children and can also determine the potential for the testes to recover and later undergo active spermatogenesis. Short-term analysis ( 1 to 5 years) and long-term analysis (6 to 10 years) following the cessation of cyclophosphamide treatment have shown that damage is often still observable in a dose- and time-dependent manner (Table 3). Patients receiving relatively high doses of cyclophosphamide have exhibited severe testicular damage with Sertoli cellonly tubules present up to 9 years after treatment (Penso et al. 1974, Aubier et al. 1989). The length of treatment regimen may also influence the disruption caused to the prepubertal testes, as shown in Etteldorf et al. (1976) (Table 3). However, such differences may ultimately be the result of higher cumulative doses or the age of the patient when treated, with younger patients potentially more at risk of reduced tubular fertility index and poor development of Sertoli and Leydig cells, as has been shown in Ise et al. (1986). Nonetheless, due to small numbers of participants, individual studies such as this can only lead to definitive conclusions when part of a larger meta-analysis. A case report has described somatic cell damage in the testis following chemotherapy during prepuberty, with the presence of immature Sertoli cells (identified by cytokeratin 18 and D2-40 markers) in a 31-year-old man treated during childhood with a regimen containing cyclophosphamide; however, causation cannot be determined from a case report (Bar-Shira Maymon et al. 2004).

\section{Summary of human studies}

The studies discussed above suggest that alkylating agents, in particular cyclophosphamide, can be detrimental to the prepubertal testis in a manner that can persist at least up to 10 years after the cessation of treatment. Since patients had received a combination of chemotherapy drugs, it is hard to determine the relative contributions of individual chemotherapeutic drugs to gonadal toxicity; in addition, results may have been influenced by the age/stage of pubertal development and each patient's own sensitivity to chemotherapy treatments.

\section{Animal studies}

The use of animal models has the potential to provide a clearer picture of chemotherapy drug-induced gonadal toxicity in the prepubertal context, in comparison to our very limited ability to investigate this directly in humans. Research on animal models enables researchers to administer drugs through more regulated regimens and to compare results using animals, tissues or cells. The use of animal models also opens the possibility of determining which period of development is more sensitive to chemotherapy treatment, for example by comparing infancy to prepuberty. Additionally, such studies are likely to be invaluable in determining the underlying mechanisms by which the different chemotherapy drugs damage the prepubertal testis, information which should help in the subsequent development of protective strategies designed to directly block such damage. Despite their great potential, relatively few studies have been conducted in vivo or in vitro with the majority of studies focusing on germ cell effects. Work to date has looked specifically at alkylating agents, anthracyclines, topoisomerase inhibitors, vinca alkaloids and non-anthracycline antibiotic chemotherapy treatments.

\section{Germ cell effects}

Alkylating and alkylating-like agents $A s$ in human studies, research to date using prepubertal testis of rodents points to alkylating and alkylating-like agents targeting the germ cell population in a dose- and timedependent manner (Table 4). SSCs have been shown to be particularly sensitive to cyclophosphamide and cisplatin, with treatment inducing DNA damage in vitro, which could ultimately activate cell death pathways if not repaired by internal DNA repair systems (Marcon et al. 2010, Liu et al. 2014). DNA damage was noted following short-term $(24 \mathrm{~h})$ exposure to chemotherapeutics using an in vitro culture system of prepubertal (pnd 5) mouse testis (Smart et al. 2018). Activation of the apoptotic pathway was shown by enhanced cleaved caspase (CC) 3 expression following cyclophosphamide and cisplatin treatment with the timings differing between the agents, followed by loss of germ cells hours later. Increased numbers of apoptotic spermatogonia and 


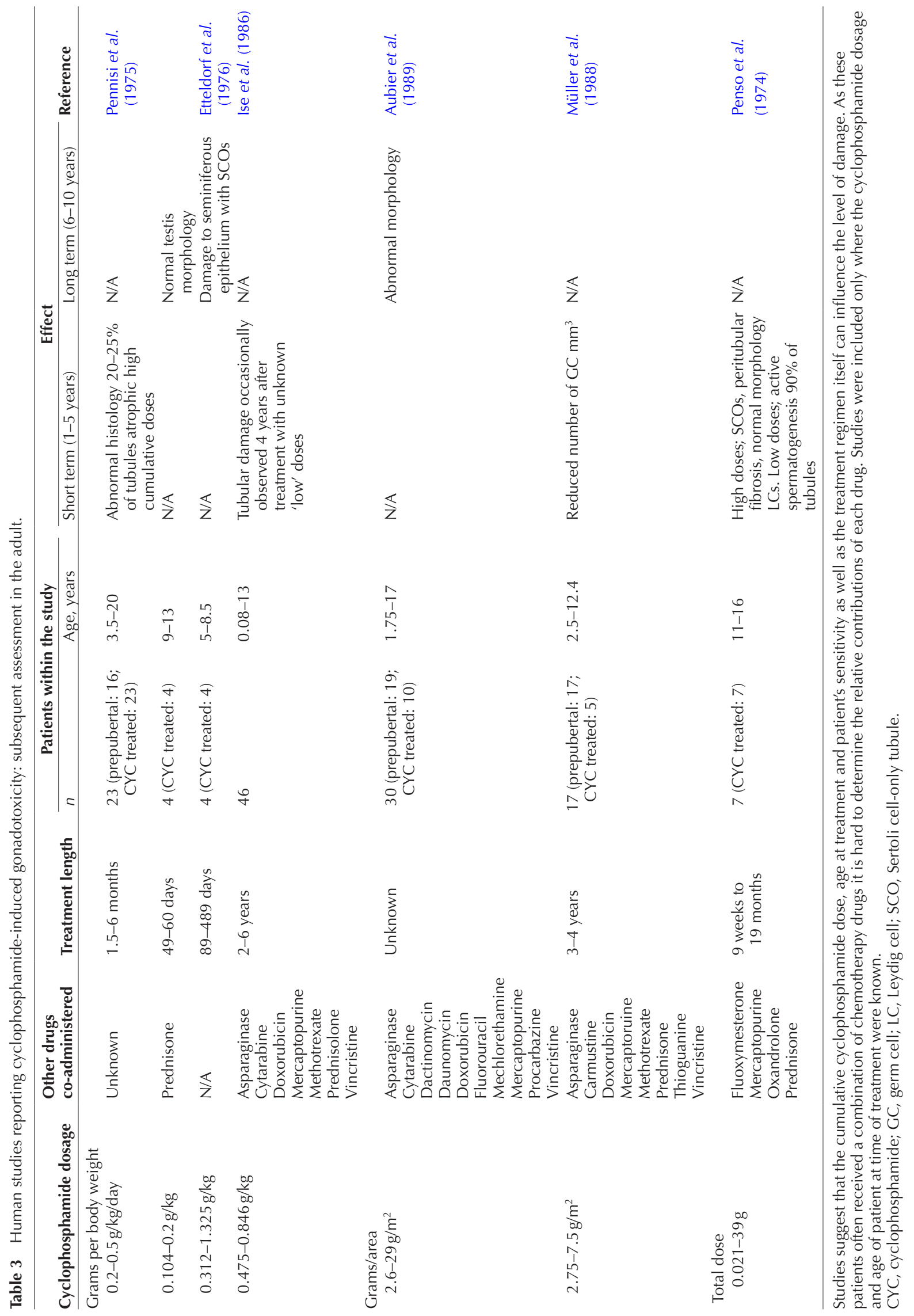


primary spermatocytes have also been observed in vivo immediately following cisplatin treatment during early puberty (pnd 30-45) in the rat and after a 45-day recovery period (Lirdi et al. 2008, Favareto et al. 2011). The length of the treatment rather than the cumulative doses appears to be involved in determining the degree of testicular damage (Velez de la Calle et al. 1989). Shorter treatment regimens reduce time of exposure of the testis to the chemotherapeutic agent, which could be more important than overall cumulative dose received.

Anthracyclines Of the anthracycline class of drugs, work to date has focused on doxorubicin, and it is clear that this drug targets the pre-mitotic dividing spermatogonia and the pre-meiotic primary spermatocytes in the prepubertal testis (Table 4). These germ cells are undergoing DNA synthesis and therefore contain high levels of the enzyme topoisomerase II, which is a target of the drug (Parvinen \& Parvinen 1978). During early prepubertal development, the testis is especially vulnerable to doxorubicin-induced damage, depleting the seminiferous epithelium in comparison to later stages shown in the rat model (Bechter et al. 1987). This study found using an immature in vivo rat model, that a relatively low dose of doxorubicin $(3 \mathrm{mg} / \mathrm{kg})$ was not sufficient to kill all the SSCs, as some recovery was apparent. In addition to inhibition of topoisomerase II activity, doxorubicin has been shown to induce DNA damage in spermatogonia in vitro, which can result in cell death (Beaud et al. 2017). Interestingly, the Beaud et al. (2017) work indicated that cell death was induced independent of apoptosis, since externalization of phosphotidylerine was not apparent following treatment. In agreement with these findings, DNA damage was observed despite the absence of a significant increase in CC3 expression prior to loss of germ cells following short-term exposure of prepubertal mouse testis tissue to doxorubicin (Smart et al. 2018). The cell death that occurs following doxorubicin may result from a nonapoptotic mechanism for example through necrosis or autophagy (Beaud et al. 2017, Smart et al. 2018). This hypothesis would be consistent with studies analysing cardiotoxicity following doxorubicin treatment where the cell death induced is through autophagy (DirksNaylor 2013). However, increased levels of CC8 and p53 $48 \mathrm{~h}$ after treatment in an in vivo model has also been reported (Hou et al. 2005). Oxidative stress has also been proposed as a mechanism of doxorubicin-induced damage to germ cells, however, work in an in vitro model culturing a cell line with rat SSC/spermatogonia type A characteristics (GC-6spg) has shown no such increase in levels of reactive oxygen species (ROS) before the onset of cytotoxicity (Tremblay \& Delbes 2018).

Topoisomerase inhibitors Topoisomerase inhibitors, such as etoposide and irinotecan, have been investigated to determine prepubertal gonadal toxicity and have been found to target the pre-mitotic and pre-meiotic germ cells (Table 4). These drugs inhibit the activity of the enzyme topoisomerase I and II and ultimately induce cell death through activation of apoptotic pathways (Freitas et al. 2002, Stumpp et al. 2004, Ortiz et al. 2009). Etoposide damages the prepubertal testis depleting the germ cell pool, with little recovery from treatment at low doses $(2 \mathrm{mg} / \mathrm{kg}$; Freitas et al. 2002). SSCs are particularly vulnerable to etoposide treatment, with a lower half maximal inhibitory dose in comparison to cisplatin and bleomycin. With etoposide targeting the SSC population, this reduction could account for the reduction in later stages of spermatogenesis observed in the adult rat (Stumpp et al. 2004, Marcon et al. 2010). Exposure of the prepubertal mouse testis in vitro to concentrations of SN38 (the metabolite of irinotecan) that reflect patient serum levels shows that this drug targets the proliferating germ cell population (Lopes et al. 2016). Involvement of the apoptotic pathway in cell death has been observed following etoposide treatment in an in vivo prepubertal rat model, with increased numbers of apoptotic intermediary and type B spermatogonia, as well as primary spermatocytes, immediately following treatment (Stumpp et al. 2004). In addition, increased activity of CC9, CC3 and CC8 as well as enhanced levels of protein and mRNA of p53 and Bcl-2 have been observed in the prepubertal rat following etoposide treatment (Ortiz et al. 2009). However, from this study it is not possible to determine which cell types within the testis the observed changes occurred in, since results were obtained from homogenised tissue.

Vinca alkaloids and non-anthracycline antibiotics In vitro studies indicate that vincristine may target the germ cell population and bleomycin has the potential to damage the testis (Table 4). Vincristine reduces cell viability and increases cell death of the GC-6spg cell line in a dose- and time-dependent manner. However, this was not a result of DNA damage, as this class of drugs inhibits polymerization of microtubules, involving activation of apoptotic pathways (Beaud et al. 2017). Bleomycin targets SSCs in vitro in a dose-dependent fashion, with cytotoxicity (seen at $0.1 \mu \mathrm{M}$ ) inducing DNA damage that extends into telomere regions of chromosomes (Marcon et al. 2010, Liu et al. 2014). These initial studies indicate that such drugs have the potential to impact the testis negatively and should be further investigated in vivo.

Combination treatments In a clinical setting, cancer is treated with a combination of chemotherapeutic agents. Different classes of drugs target cells through differing mechanisms which may have synergistic effects. The combined treatments reduce the chance of resistance and survival of cancerous cells, but have the possibility 


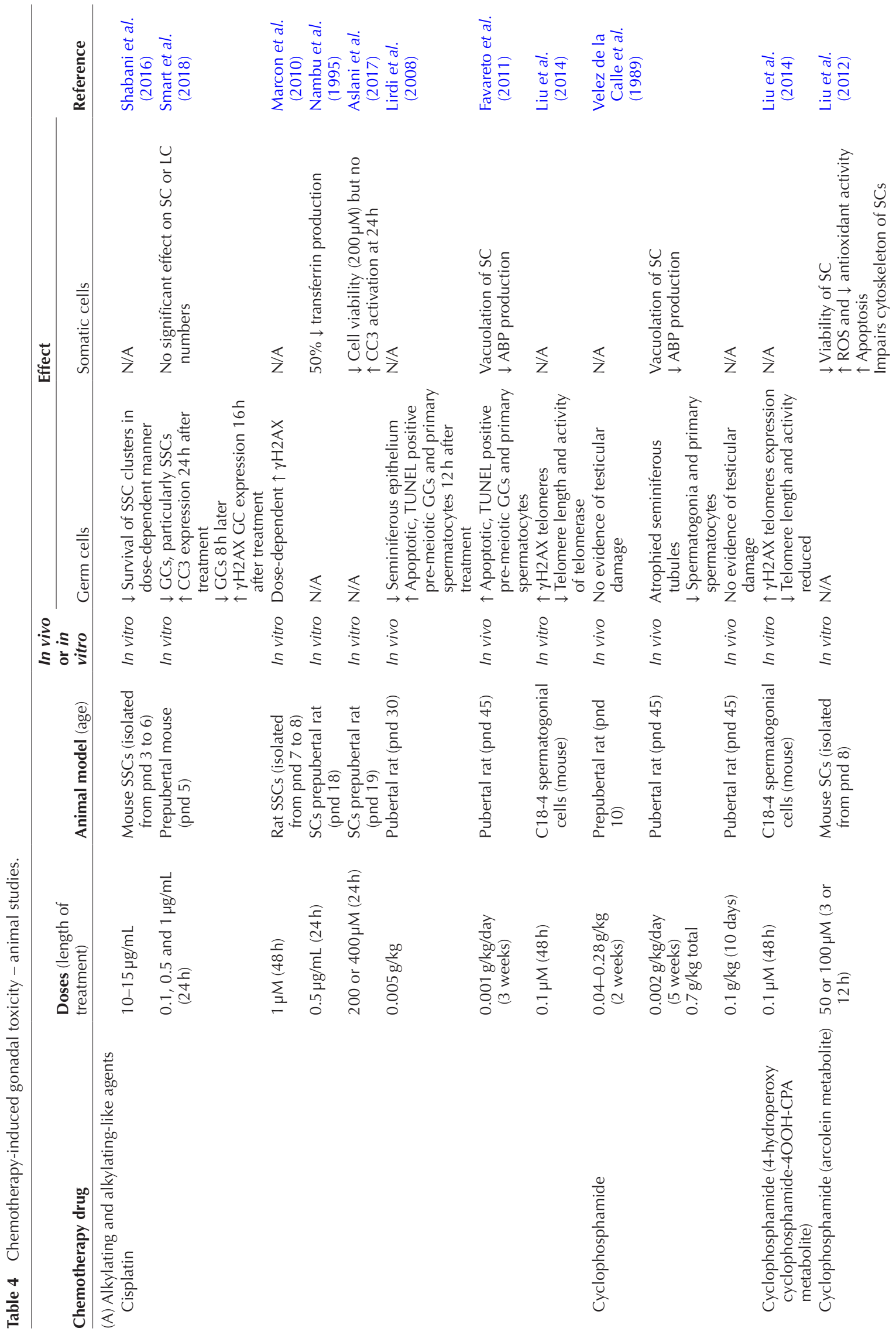




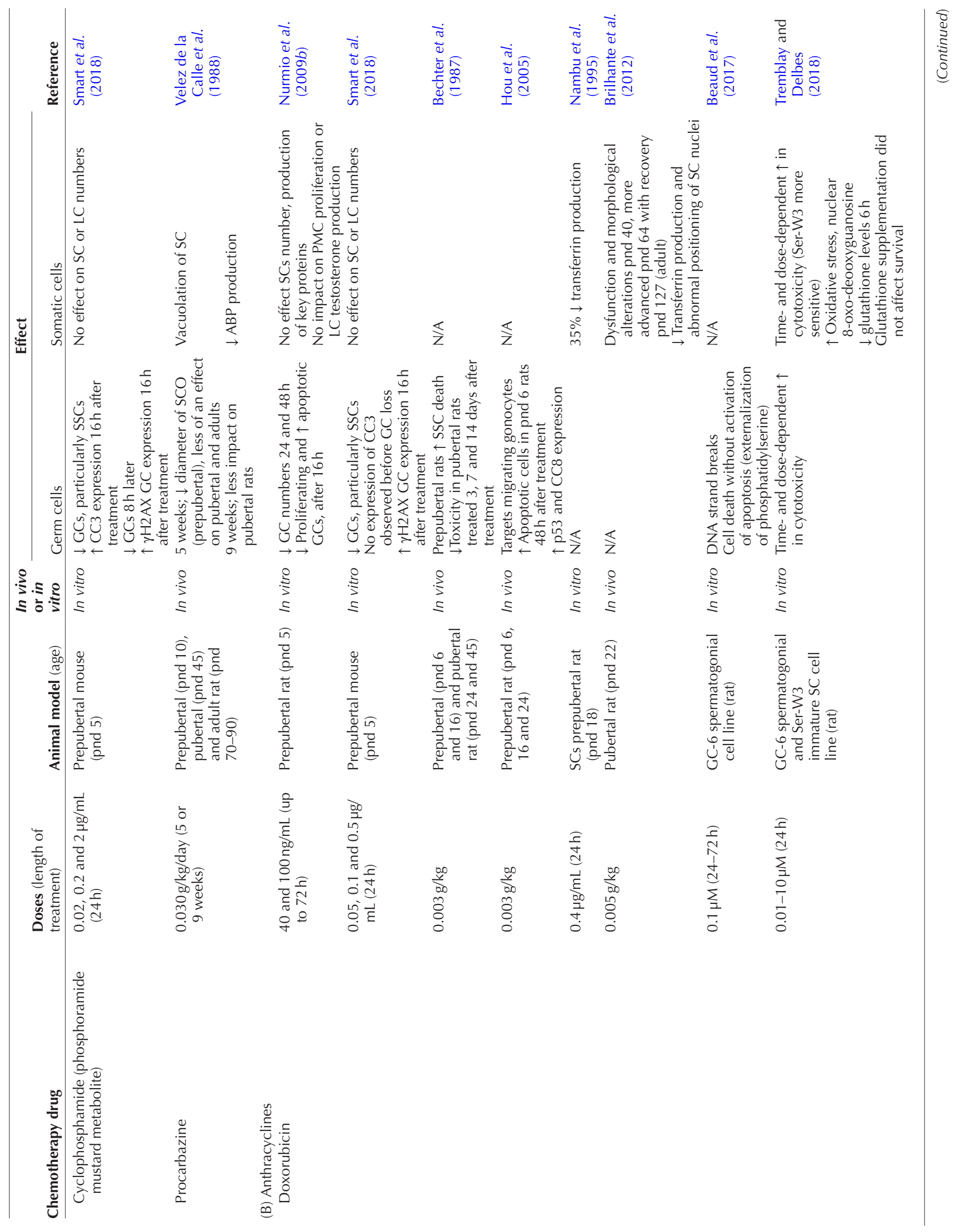




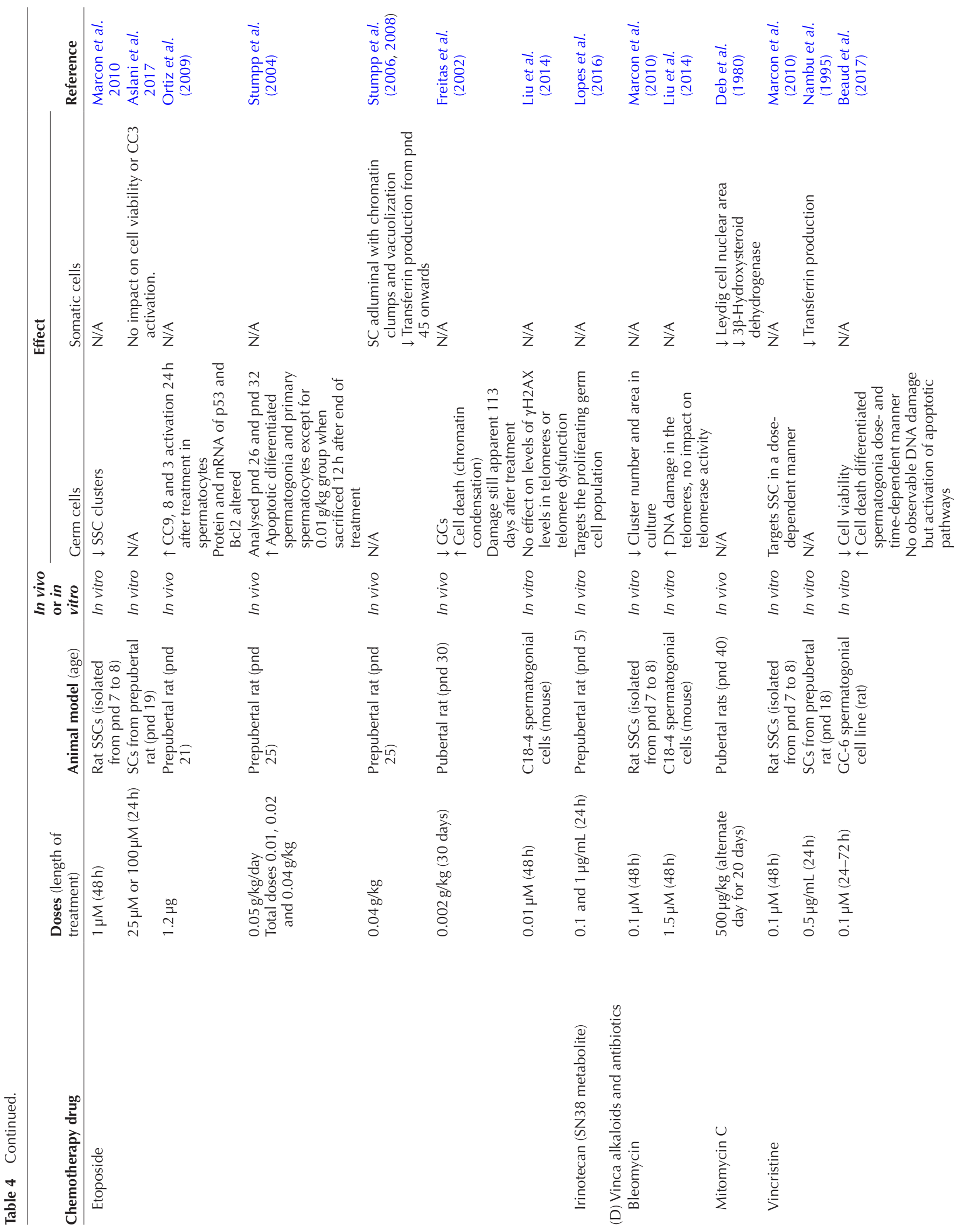




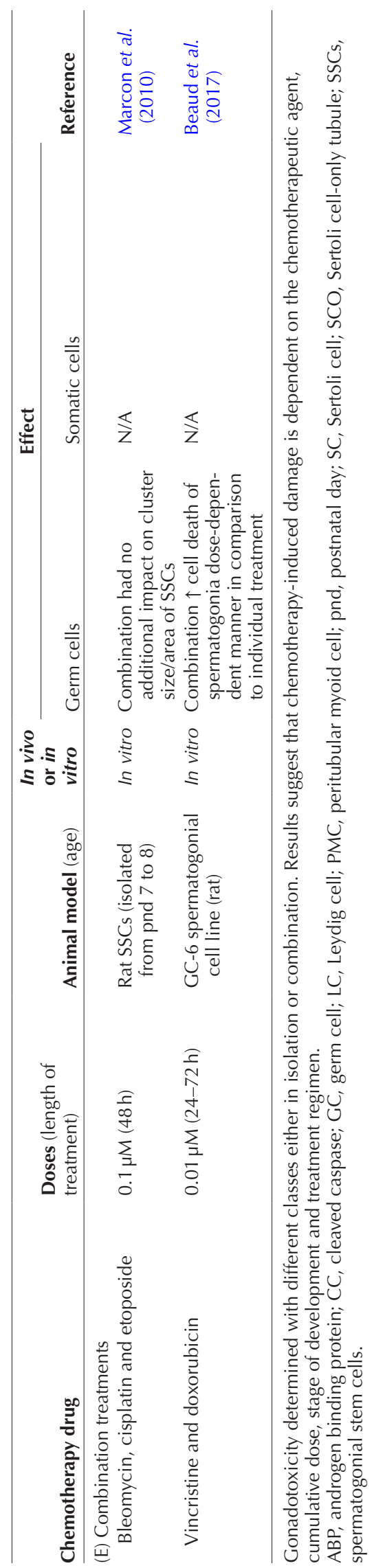

of leading to multiplicative off-target side effects on healthy cells. Relatively few animal studies have focused on combinations of drugs (Table 4). Using the GC-6spg cell line, Beaud et al. (2017) showed that a combination of vincristine and doxorubicin enhanced levels of cell death in a dose-dependent manner in comparison to treatment with each drug individually. In contrast, exposure to a combination of bleomycin, cisplatin and etoposide had no additional impact on cluster size/area of mouse SSCs in culture (Marcon et al. 2010). Further investigations into common combinations are required to determine the relative gonadotoxicity, and whether the effects are synergistic and/or multiplicative.

\section{Somatic cell effects}

Studies relating to impacts of chemotherapy treatment upon the somatic cells have mainly been limited to the Sertoli cell and include studies which have focused on cyclophosphamide, cisplatin, doxorubicin and etoposide chemotherapy agents (Table 4). Treatment results in morphological damage including vacuolation of the cells and adluminal positioning (Velez de la Calle et al. 1988, 1989, Stumpp et al. 2006, 2008, Favareto et al. 2011, Brilhante et al. 2012). However, these cells do survive exposure as shown in Smart et al. (2018) where there was no overall change in cell numbers following cyclophosphamide, cisplatin or doxorubicin treatment in an in vitro model of prepubertal mouse testicular tissue. Damage to the Sertoli cells resulting in dysfunction could be the primary effect of such treatment, which would have a significant impact on testis function. Indeed, decreased production of androgen-binding protein following treatment with alkylating and alkylating-like agents has been reported in prepubertal rats (Velez de la Calle et al. 1988, 1989, Favareto et al. 2011). In vitro studies using primary cultures of rat Sertoli cells have also shown reduced transferrin production following cisplatin, doxorubicin and vincristine treatment (Nambu et al. 1995). Transferrin stimulates germ cell proliferation/ differentiation by transferring iron to these cells (Sylvester \& Griswold 1994). A potential mechanism by which cyclophosphamide and doxorubicin induce damage specifically to the Sertoli cell has been proposed by in vitro studies of cultured immature Sertoli cells where enhanced levels of oxidative stress have been reported (Liu et al. 2012, Tremblay \& Delbes 2018) as well as damage to the cytoskeleton following cyclophosphamide treatment (Liu et al. 2012).

Impairment of Sertoli cell functionality, however, may be secondary and a result of primary injury to the germ cell population. An in vivo study looking at doxorubicininduced damage has shown that the alterations in the morphology and function of these cells was more pronounced in early adulthood in comparison to time of treatment just before puberty (pnd 22). This suggests that the germ cells were the primary cells targeted 
by doxorubicin, with loss/damage to the germ cells ultimately impacting Sertoli cells as a secondary effect (Brilhante et al. 2012). For etoposide, functional deficits were also more apparent in adulthood, suggesting damage was secondary to germ cell death. However, upon recovery of the seminiferous epithelium, Sertoli cell dysfunction was still apparent with reduced transferrin production and altered morphology; this may suggest a degree of primary damage on the Sertoli cells (Stumpp et al. 2006). How to distinguish between primary and secondary damage to the Sertoli cells is difficult due to the dependence of Sertoli cells on germ cells and vice versa. Isolation of Sertoli cells from the germ cell population, as with the primary cell culture or established cell line culture experiments, has been used to look specifically at Sertoli cell damage. These isolated Sertoli cells, however, may not be representative of the 'true' in vivo Sertoli cell as often these cells do not maintain Sertoli cell identity once removed from their true environment, a limitation that needs to be borne in mind for all cell line studies.

To date, few studies have focused on the other somatic cell types within testis, the Leydig cells or peritubular myoid cells. An in vivo study reported reduced steroidogenic activity of Leydig cells following treatment of immature rats with mitomycin C (Deb et al. 1980). More recent in vitro studies have shown there was no change in Leydig cells numbers reported by Smart et al. (2018) after in vitro exposure of mouse prepubertal testis fragments to cisplatin, cyclophosphamide and doxorubicin. The proliferative ability of the peritubular myoid cells and steroidogenic activity of the Leydig cells were also unaltered after doxorubicin treatment of rat testis tissue in vitro (Nurmio et al. 2009b). Additional studies looking specifically at these cell types within the testis are required before any conclusion can be drawn on chemotherapy-induced damage.

\section{Summary of animal studies}

To conclude, in the prepubertal testes chemotherapy agents have been shown to specifically target and deplete the germ cell pool, in some cases specifically the SSC population, with DNA damage noted after cyclophosphamide, cisplatin and doxorubicin exposure. Apoptosis is the main cell death pathway activated by cyclophosphamide, cisplatin, etoposide and vincristine exposure, whereas doxorubicin-induced testicular damage may be the result of an alternative cell death pathway such as necrosis or autophagy. Cancer therapy may also affect the Sertoli cell population resulting in morphological damage and/or dysfunction, as shown by cyclophosphamide, procarbazine, cisplatin, doxorubicin and etoposide treatment. However, somatic cell impairment may either be the result of primary cellular damage to the Sertoli cells themselves and/or a secondary consequence of targeted loss of the germ cell population. Whether combined chemotherapy treatment regimens modify the toxicity of individual drugs needs further clarification, as few such in vitro studies have been performed to date.

\section{Effects on future generations}

The clinical impact of prepubertal chemotherapy treatment on later fertility has been discussed in several reviews (Hudson 2010, Lee \& Shin 2013); for survivors who are able to conceive there could be potential effects upon future generations due to unrepaired damage to the male germline. The impact on future generations is not yet clear. A Danish study of 472 survivors of childhood cancer found no significant association between alkylating chemotherapy treatment and later genetic diseases of the progeny of these survivors (Winther et al. 2012). Nonetheless, a study by Liu et al. (2014) has shown a potential mechanism by which alkylating agents can impact on future generations by targeting the telomeres of mouse spermatogonial cells. Telomerase function was reduced at concentrations of a drug precursor of cyclophosphamide $(4 \mathrm{OOH}-\mathrm{CPA})$ and cisplatin which induced significant spermatogonial cell death resulting in reduced telomere length and activity of telomerase. A reduction in the length or function of telomeres of the male germ cell can adversely affect early development of the offspring, increasing the rate of preand/or post-implantation loss, congenital malformation and miscarriage (Liu et al. 2002). Whether additional classes of drugs also impact on future generations is unknown and therefore further research into this area is urgently required.

\section{Protective strategies}

The development of chemotherapeutic treatment regimens has increased greatly in the past decade resulting in a greater number of childhood cancer survivors reaching adulthood and facing long-term consequences of treatment, such as infertility. There is therefore an increasing focus on preserving the fertility of children undergoing cancer treatment. At the time of writing, though, fertility preservation strategies for prepubertal boys have yet to be established clinically. Testicular tissue from boys undergoing 'high' risk chemotherapy treatment is being collected in a limited number of centres, with tissue cryopreserved and stored for potential fertility restoration when the boys reach adulthood. The proposed techniques to restore fertility, however, are still in the experimental phase of development with success to date only in rodent models (Picton et al. 2015, Giudice et al. 2017). Studies with human tissues have been conducted in relation to transplantation of cryopreserved testicular tissue and SSCs as well as in vitro maturation of immature testicular tissue, paving the way for the development of a fertility restoration 
method clinically (reviewed Giudice et al. 2017). Xenotransplantation of prepubertal human testicular tissue for up to 9 months has been performed with nude mice where initiation of spermatogenesis was observed within the grafted tissue, however spermatogenesis did not reach meiotic differentiation (Wyns et al. 2007, 2008, Goossens et al. 2008, Van Saen et al. 2011, 2013). SSCs isolated from prepubertal patients have been propagated in vitro, but results are preliminary (SadriArekani et al. 2011). Human prepubertal testicular tissue has been successfully cultured in vitro with survival of the spermatogonial germ cell population, maturation of the somatic cells and formation of the blood-testis barrier reported (de Michele et al. 2017, 2018). Initiation of spermatogenesis from such tissue has yet to be demonstrated. Alternatively, the prepubertal testis could be protected against injury caused by the treatment through use of cytoprotective agents that would be added to the cancer treatment regimen. Several studies have shown the gonadoprotective potential of agents in animal studies focusing on adult males, mainly investigating the morphology and motility of sperm. For example, Carmely et al. (2009) has shown in a mouse model the cytoprotective effect of the immunomodulator AS101 compound against cyclophosphamide-induced testicular damage. In contrast, so far only a limited number of compounds have been analysed to determine their ability to protect the prepubertal testis in an animal model (Table 5).

\section{Amifostine}

Amifostine is an organic thiophosphate that acts as a cytoprotective agent, protecting cells against chemotherapeutic damage whilst having no antitumor activity (Çetingül et al. 2009). The active metabolite acts as a ROS scavenger and binds and stabilizes DNA (Spencer \& Goa 1995). This drug has a limited half-life of eight minutes, therefore in vivo studies have focused on pre-treatment of amifostine $15 \mathrm{~min}$ before chemotherapy treatment. Pre-treatment partially protected the prepubertal rat testis against cisplatin- and doxorubicininduced testicular damage; this effect may be dependent on the age and schedule of treatment, as a lower dose of amifostine in earlier stages of prepubertal development in rats had no protective effects against doxorubicininduced damage when tissues were analysed 24 and $48 \mathrm{~h}$ after treatment (Jahnukainen et al. 2001, Hou et al. 2005). However, prepubertal amifostine pre-treatment before doxorubicin treatment did not maintain fertility in the adult, as DNA damage was found in the sperm of treated animals when analysed 64 days after treatment, which increased the number of arrested embryos in a mating study of adults (100 days old) (Vendramini et al. 2012). An in vitro study has also indicated that amifostine has no protective effects against doxorubicininduced damage in a spermatogonial cell line and an immature Sertoli cell line (Tremblay \& Delbes 2018). Therefore, amifostine may not be a suitable fertility preservation strategy.

\section{Carnitine}

Carnitine is a quaternary amine found at high concentrations within the epididymis of the male reproductive tract and in spermatozoa. It is acquired through dietary meat and milk and is also produced by the liver through methylation of lysine and methionine amino acids. This compound has essential roles in determining male fertility, producing energy by transferring long-chain fatty acids into mitochondria, a process required for germ cell maturation, sperm motility and sperm count; it has been shown to have cytoprotective properties whilst having no impact on anticancer treatment efficacy (Chiu et al. 2004, Sayed-Ahmed 2010). Partial protection from etoposide and doxorubicin-induced morphological damage and apoptotic germ cell death was shown when prepubertal rats were pre-treated with carnitine one hour before chemotherapy treatment in vivo (Okada et al. 2009, Cabral et al. 2014). The mechanism underlying such cytoprotective action is unknown, but may be the result of enhanced DNA repair activity, inhibition of ceramide production and/or reduction in oxidative stress-induced damage as shown in a range of different cell types (Andrieu-Abadie et al. 1999, Palmero et al. 2000, Alshabanah et al. 2010). Indeed, a study by Cabral et al. (2018) has shown improved oxidative stress status of the adult testis following prepubertal pre-treatment with cartinine one hour before doxorubicin treatment in a rodent model. An in vitro model, however, has found no protective effects against doxorubicin-induced damage when cartinine is administered in spermatogonial or immature Sertoli cell lines (Tremblay \& Delbes 2018). Sertoli cell function may be improved upon carnitine administration, as these cells express carnitine/organic cation transport 2 receptors, with carnitine important in the maintenance of the BTB (Palmero et al. 2000).

\section{Ginseng intestinal metabolite I (GIM-I)}

The herbal root, Ginseng has been used in East Asian countries as a traditional Chinese medicine and the intestinal metabolite, known as ginseng intestinal metabolite I (GIM-I), is thought to have multiple pharmacological effects through its antioxidant activity (Zhang et al. 1996). The protective effect against doxorubicin-induced damage has been analysed by Kang et al. (2002) in prepubertal mice in vivo, where GIM-I was found to partially protect against doxorubicin-induced germ cell damage resulting in testicular morphology comparable to controls that may be the result of enhanced antioxidant activity. GIM-I 
Table 5 Potential cytoprotective agents to protect the prepubertal testis against chemotherapy-induced damage.

\begin{tabular}{|c|c|c|c|c|c|c|}
\hline Compound & Dose & Chemotherapy drug/doses & Animal model/age & $\begin{array}{l}\text { In vivo or } \\
\text { in vitro }\end{array}$ & Effect & Reference \\
\hline Amifostine & $0.2 \mathrm{~g} / \mathrm{kg}$ & Doxorubicin $0.003 \mathrm{~g} / \mathrm{kg}$ & Prepubertal rat (pnd 6) & In vivo & No protective effects & $\begin{array}{l}\text { Jahnukainen } \\
\text { et al. (2001), } \\
\text { Hou et al. } \\
(2005)\end{array}$ \\
\hline Amifostine & $0.4 \mathrm{~g} / \mathrm{kg}$ & Cisplatin $0.005 \mathrm{~g} / \mathrm{kg}$ & $\begin{array}{l}\text { Prepubertal rat } \\
\text { (pnd 30) }\end{array}$ & In vivo & $\begin{array}{l}\text { Partial protection, } \downarrow \\
\text { seminiferous tubule } \\
\text { area and } \uparrow \text { apoptotic } \\
\text { spermatogonia and } \\
\text { primary } \\
\text { spermatocytes }\end{array}$ & Lirdi et al. (2008) \\
\hline Amifostine & $0.4 \mathrm{~g} / \mathrm{kg}$ & Doxorubicin $0.005 \mathrm{~g} / \mathrm{kg}$ & $\begin{array}{l}\text { Prepubertal rat } \\
\text { (pnd 30) }\end{array}$ & In vivo & $\begin{array}{l}\text { Partially protects. Did } \\
\text { not protect against } \\
\text { DNA damage and } \\
\text { negatively impacted } \\
\text { on embryo } \\
\text { development and } \\
\text { pregnancy outcome }\end{array}$ & $\begin{array}{l}\text { Vendramini et al. } \\
(2010,2012)\end{array}$ \\
\hline Amifostine & $1 \mu \mathrm{M}$ & Doxorubicin $0.01-1 \mu \mathrm{M}(24 \mathrm{~h})$ & $\begin{array}{l}\text { GC-6 spermatogonial } \\
\text { and Ser-W3 immature } \\
\text { SC cell line (rat) }\end{array}$ & In vitro & $\begin{array}{l}\text { Pre-treatment for } 24 \mathrm{~h} \\
\text { or co-treatment had } \\
\text { no impact on } \\
\text { cytotoxicity in the } \\
\text { Ser-W3 cell line }\end{array}$ & $\begin{array}{l}\text { Tremblay \& } \\
\text { Delbes (2018) }\end{array}$ \\
\hline Cartinine & $0.25 \mathrm{~g} / \mathrm{kg}$ & Etoposide $0.04 \mathrm{~g} / \mathrm{kg}$ & Prepubertal rat (pnd25) & In vivo & $\begin{array}{l}\text { Analysed pnd 30, } 64 \\
\text { and } 100 \text {. Partial } \\
\text { protection, reduction } \\
\text { in TUNEL+ cells }\end{array}$ & $\begin{array}{l}\text { Okada et al. } \\
(2009)\end{array}$ \\
\hline Cartinine & $0.25 \mathrm{~g} / \mathrm{kg} /$ day & Doxorubicin $0.005 \mathrm{~g} / \mathrm{kg}$ & Prepubertal rat (pnd30) & In vivo & $\begin{array}{l}\text { Analysed pnd } 64 \text { and } \\
100 . \text { Partial } \\
\text { protection, } \downarrow \text { TUNEL+ } \\
\text { cells and sperm DNA } \\
\text { damage. } \uparrow \text { Acrosome } \\
\text { integrity pre- } \\
\text { treatment, no impact } \\
\text { on sperm motility and } \\
\text { mitochondrial } \\
\text { activity. } \downarrow \text { Lipid } \\
\text { peroxidation and } \\
\text { nitric oxide. } \uparrow \text { Fertility } \\
\text { index and } \\
\text { implantation rate } \\
\text { improved }\end{array}$ & $\begin{array}{l}\text { Cabral et al. } \\
(2014,2018)\end{array}$ \\
\hline Cartinine & $10 \mathrm{mM}$ & Doxorubicin $0.01-1 \mu \mathrm{M}(24 \mathrm{~h})$ & $\begin{array}{l}\text { GC-6 spermatogonial } \\
\text { and Ser-W3 immature } \\
\text { SC cell line (rat) }\end{array}$ & In vitro & $\begin{array}{l}\text { Pre-treatment for } 24 \mathrm{~h} \\
\text { or co-treatment had } \\
\text { no impact on } \\
\text { cytotoxicity in the } \\
\text { Ser-W3 cell line }\end{array}$ & $\begin{array}{l}\text { Tremblay \& } \\
\text { Delbes (2018) }\end{array}$ \\
\hline Curcumin & $5 \mu \mathrm{M}$ & Doxorubicin $0.01-1 \mu \mathrm{M}(24 \mathrm{~h})$ & $\begin{array}{l}\text { GC-6 spermatogonial } \\
\text { and Ser-W3 immature } \\
\text { SC cell line (rat) }\end{array}$ & In vitro & $\begin{array}{l}\text { Pre-treatment for } 24 \mathrm{~h} \\
\text { or co-treatment had } \\
\text { no impact on } \\
\text { cytotoxicity in the } \\
\text { Ser-W3 cell line }\end{array}$ & $\begin{array}{l}\text { Tremblay \& } \\
\text { Delbes (2018) }\end{array}$ \\
\hline $\begin{array}{l}\text { Ginseng } \\
\text { intestinal } \\
\text { metabolite I } \\
\text { (GIM-I) }\end{array}$ & $0.05 \mathrm{~g} / \mathrm{kg} / \mathrm{day}$ & Doxorubicin $0.05 \mathrm{~g} / \mathrm{kg} /$ day & Prepubertal rat (pnd28) & In vivo & Partially protects & Kang et al. (2002) \\
\hline Vitamin C & $40 \mu \mathrm{g} / \mathrm{mL}$ & Doxorubicin $0.01-1 \mu \mathrm{M}(24 \mathrm{~h})$ & $\begin{array}{l}\text { GC-6 spermatogonial } \\
\text { and Ser-W3 } \\
\text { immature SC cell line } \\
\text { (rat) }\end{array}$ & In vitro & $\begin{array}{l}\text { Pre-treatment for } 24 \mathrm{~h} \\
\text { or co-treatment had } \\
\text { no impact on cytotox- } \\
\text { icity in the Ser-W3 } \\
\text { cell line }\end{array}$ & $\begin{array}{l}\text { Tremblay \& } \\
\text { Delbes (2018) }\end{array}$ \\
\hline
\end{tabular}

increases the levels of testis-specific antioxidants which were reduced following doxorubicin treatment. This compound has great potential as a cytoprotective agent against doxorubicin-induced damage and appears to have anti-metastatic activity and could therefore be added to chemotherapeutic regimens to provide benefit as both a cytotoxic and cytoprotective agent (Hasegawa et al. 1997). 


\section{Vitamin C and curcumin}

A study by Tremblay and Delbes (2018) has investigated the potential of compounds as cytoprotectants based upon their antioxidant activity, including vitamin $\mathrm{C}$ and curcumin. Vitamin C can also function by inhibiting apoptosis, whilst curcumin has additional anti-inflammatory properties. However, in both cases treatment did not reduce the cytotoxic activity of doxorubicin in either spermatogonial or immature Sertoli cell lines. This study therefore indicates that these compounds may not be suitable cytoprotectants against doxorubicin-induced prepubertal testicular damage.

\section{Summary of protective strategies}

Cytoprotective agents could play a major role in the future of fertility preservation strategies, however, research in this area to date is very limited, and has only shown partial protection against chemotherapy-induced damage with pre-treatment with amifostine, cartinine and GIM-I. Moreover, prepubertal amifostine treatment alone compromised later fertility and is therefore not suitable for purpose. In contrast, GIM-I might have more potential as a cytoprotective agent, in part due to its anti-metastatic activity. Overall, despite the promising results outlined, the level of evidence established so far in animal studies in not sufficient for transfer to clinical practise and needs further investigation.

\section{Conclusion}

This review has provided an overview of what is currently known in relation to chemotherapy-induced prepubertal testicular toxicity from studies in human patients and animal models, focusing primarily upon direct damage following chemotherapy exposure. Cancer therapy with a range of chemotherapy agents from different drug classes during childhood have been found to negatively impact upon the prepubertal testis. The resulting damage depends on the compounds used, cumulative dose, administration regimen and age/pubertal status during treatment. Such conclusions have been drawn from both clinical investigations and animal models, including in vivo as well as in vitro studies, with testicular fragments or primary cell cultures/cell lines representatives of the cell types in the prepubertal testis. However, as this review has discussed, the evidence for chemotherapyinduced damage to the prepubertal testis is at present incomplete and needs further investigation.

Further research into chemotherapy-induced prepubertal testicular toxicity is essential as the number of childhood cancer survivors is set to increase steadily over the coming years. Enhancing our knowledge of the gonadotoxicity of chemotherapeutic agents is essential for clinicians to determine which patients to offer cryopreservation of immature testicular tissue for potential fertility restoration strategies, which are at present experimental for human patients. Understanding how chemotherapy agents target and damage the testis of young boys will provide much clarity to the future quality of life of these patients and aid in the development of protective strategies for preservation of fertility.

\section{Declaration of interest}

Norah Spears is a member of the Editorial Board of Reproduction. None of the other authors has any conflict of interest.

\section{Funding}

Funding by Children with Cancer UK (grant \#15-198). R M's work was undertaken in the MRC Centre for Reproductive Health funded by MRC Centre Grant MR/N022556/1, and C A was supported by Career Development PhD Scholarship in Biomedical Sciences funded by the Biomedical Sciences ZJU project. Thanks to Kathleen Duffin for comments on an earlier draft.

\section{References}

Abofoul-Azab M, AbuMadigem A, Lunenfeld E, Kapelushnik J, Shi Q, Pinkas H \& Huleihel M 2018 Development of postmeiotic cells in vitro from spermatogonial cells of prepubertal cancer patients. Stem Cells and Development 271007-1020. (https://doi.org/10.1089/scd.2017.0301)

Alshabanah OA, Hafez MM, Al-Harbi MM, Hassan ZK, Al Rejaie SS, Asiri YA \& Sayed-Ahmed MM 2010 Doxorubicin toxicity can be ameliorated during antioxidant L-carnitine supplementation. Oxidative Medicine and Cellular Longevity 3 428-433. (https://doi.org/10.4161/ oxim.3.6.14416)

Anderson RA, Mitchell RT, Kelsey TW, Spears N, Telfer EE \& Wallace WHB 2015 Cancer treatment and gonadal function: experimental and established strategies for fertility preservation in children and young adults. Lancet Diabetes and Endocrinology 8587 1-12. (https://doi. org/10.1016/S2213-8587(15)00039-X)

Andrieu-Abadie N, Jaffrezou JP, Hatem S, Laurent G, Levade T \& Mercadier JJ 1999 L-Carnitine prevents doxorubicin-induced apoptosis of cardiac myocytes: role of inhibition of ceramide generation. FASEB Journal 13 1501-1510. (https://doi.org/10.1096/fasebj.13.12.1501)

Arneil GC 1972 Cyclophosphamide and the prepubertal testis. Lancet 2 1259-1260. (https://doi.org/10.1016/S0140-6736(72)92321-5)

Aslani F, Sebastian T, Keidel M, Fröhlich S, Elsässer H, Schuppe H, Klug J, Mahavadi P, Fijak M, Bergmann M et al. 2017 Resistance to apoptosis and autophagy leads to enhanced survival in Sertoli cells. Molecular Human Reproduction 23 370-380. (https://doi.org/10.1093/molehr/ gax022)

Aubier F, Flamant F, Brauner R, Caillaud JM, Chaussain JM \& Lemerle J 1989 Male gonadal function after chemotherapy for solid tumors in childhood. Journal of Clinical Oncology 7 304-309. (https://doi. org/10.1200/JCO.1989.7.3.304)

Bar-Shira Maymon B, Yogev L, Marks A, Hauser R, Botchan A \& Yavetz H 2004 Sertoli cell inactivation by cytotoxic damage to the human testis after cancer chemotherapy. Fertility and Sterility 81 1391-1394. (https:// doi.org/10.1016/j.fertnstert.2003.09.078)

Beaud H, Pelt AV \& Delbes G 2017 Doxorubicin and vincristine affect undifferentiated rat spermatogonia. Reproduction 153 725-735. (https:// doi.org/10.1530/REP-17-0005)

Bechter R, Haebler R, Ettlin RA, Haseman JK \& Dixon RL 1987 Differential susceptibility of immature rat testes to doxorubicin at critical stages of maturation. Archives of Toxicology 60 415-421. (https://doi.org/10.1007/ BF00302383) 
Berry CL, Cameron JS, Ogg CS, Trounce D \& Turner DR 1972 Cyclophospamide and the prepubertal testis. Lancet 300 1033-1034. (https://doi.org/10.1016/S0140-6736(72)92448-8)

Brehm R, Rey R, Kliesch S, Steger K, Marks A \& Bergmann M 2006 Mitotic activity of Sertoli cells in adult human testis: an immunohistochemical study to characterize Sertoli cells in testicular cords from patients showing testicular dysgenesis syndrome. Anatomy and Embryology 211 223-236. (https://doi.org/10.1007/s00429-005-0075-8)

Brilhante O, Okada FK, Sasso-Cerri E, Stumpp T \& Miraglia SM 2012 Late morfofunctional alterations of the Sertoli cell caused by doxorubicin administered to prepubertal rats. Reproductive Biology and Endocrinology 10 79. (https://doi.org/10.1186/1477-7827-10-79)

Brinster RL \& Zimmermann JW 1994 Spermatogenesis following male germ-cell transplantation. PNAS 91 11298-11302. (https://doi. org/10.1073/pnas.91.24.11298)

Cabral REL, Okada FK, Stumpp T, Vendramini V \& Miraglia SM 2014 Carnitine partially protects the rat testis against the late damage produced by doxorubicin administered during pre-puberty. Andrology 2 931-942. (https://doi.org/10.1111/andr.279)

Cabral REL, Mendes TB, Vendramini V \& Miraglia SM 2018 Carnitine partially improves oxidative stress, acrosome integrity, and reproductive competence in doxorubicin-treated rats. Andrology 6 236-246. (https:// doi.org/10.1111/andr.12426)

Cancer Research UK 2015 Children's Cancer Statistics. Cancer Research UK.

Carmely A, Meirow D, Peretz A, Albeck M, Bartoov B \& Sredni B 2009 Protective effect of the immunomodulator AS101 against cyclophosphamide-induced testicular damage in mice. Human Reproduction 24 1322-1329. (https://doi.org/10.1093/humrep/den481)

Çetingül N, Midyat L, Kantar M, Demiră̆ B, Aksoylar S \& Kansoy S 2009 Cytoprotective effects of amifostine in the treatment of childhood malignancies. Pediatric Blood and Cancer 52 829-833. (https://doi. org/10.1002/pbc.21959)

Chemes HE 2001 Infancy is not a quiescent period of testicular development. International Journal of Andrology $242-7$. (https://doi. org/10.1046/j.1365-2605.2001.00260.x)

Chen H, Ge RS \& Zirkin BR 2009 Leydig cells: from stem cells to aging. Molecular and Cellular Endocrinology 306 9-16. (https://doi. org/10.1016/j.mce.2009.01.023)

Chiu MN, Blackman MR, Wang C \& Swerdloff RS 2004 The role of carnitine in the male reproductive system. Annals of the New York Academy of Sciences 1033 177-188. (https://doi.org/10.1196/annals.1320.017)

Chow EJ, Stratton KL, Leisenring WM, Oeffinger KC, Sklar CA, Donaldson SS, Ginsberg JP, Kenney LB, Levine JM, Robison LL et al. 2016 Pregnancy after chemotherapy in male and female survivors of childhood cancer treated between 1970 and 1999: a report from the Childhood Cancer Survivor Study cohort. Lancet Oncology 17 567-576. (https://doi.org/10.1016/S1470-2045(16)00086-3)

Copeland KC \& Chernausek S 2016 Mini-puberty and growth. Pediatrics 138 1-2. (https://doi.org/10.1542/peds.2015-4268B)

Corrie PG 2011 Cytotoxic chemotherapy: clinical aspects. Medicine 39 717-722. (https://doi.org/10.1016/j.mpmed.2011.09.012)

Culty M 2009 Gonocytes, the forgotten cells of the germ cell lineage. Birth Defects Research Part C: Embryo Today: Reviews 87 1-6. (https://doi. org/10.1002/bdrc.20142)

de Michele F, Poels J, Weerens L, Petit C, Evrard Z, Ambroise J, Gruson D \& Wyns C 2017 Preserved seminiferous tubule integrity with spermatogonial survival and induction of Sertoli and Leydig cell maturation after longterm organotypic culture of prepubertal human testicular tissue. Human Reproduction 32 32-45. (https://doi.org/10.1093/humrep/dew300)

de Michele F, Poels J, Giudice M, De Smedt F, Ambroise J, Vermeulen M, Gruson D \& Wyns C 2018 In-vitro formation of the blood-testis barrier during long-term organotypic culture of human prepubertal tissue: comparison with a large cohort of pre/peripubertal boys. MHR: Basic Science of Reproductive Medicine 24 271-282. (doi:10.1093/molehr/ gay012)

de Rooij DG \& Russell LD 2000 All you wanted to know about spermatogonia but were afraid to ask. Journal of Andrology 21 776-798.

Deb C, Banik S, Paul B, Mukherjee R \& Ghosh K 1980 Action of mitomycin $\mathrm{C}$ on testicular steroidogenesis and its probable mode of action in albino rats. Andrologia 12 276-280. (https://doi.org/10.1111/j.1439-0272.1980. tb00629.x)
Dere E, Anderson LM, Hwang K \& Boekelheide K 2013 Biomarkers of chemotherapy-induced testicular damage. Fertility and Sterility $\mathbf{1 0 0}$ 1192-1202. (https://doi.org/10.1016/j.fertnstert.2013.09.017)

Dirks-Naylor AJ 2013 The role of autophagy in doxorubicin-induced cardiotoxicity. Life Sciences 93 913-916. (https://doi.org/10.1016/j. Ifs.2013.10.013)

Ehmcke J, Wistuba J \& Schlatt S 2006 Spermatogonial stem cells: questions, models and perspectives. Human Reproduction Update 12 275-282. (https://doi.org/10.1093/humupd/dmk001)

Etteldorf JN, West CD, Pitcock JA \& Williams DL 1976 Gonadal function, testicular histology, and meiosis following cyclophosphamide therapy in patients with nephrotic syndrome. Journal of Pediatrics 88 206-212. (https://doi.org/10.1016/S0022-3476(76)80983-3)

Favareto APA, Fernandez CDB, da Silva DAF, Anselmo-Franci JA \& Kempinas WDG 2011 Persistent impairment of testicular histology and sperm motility in adult rats treated with cisplatin at peri-puberty. Basic and Clinical Pharmacology and Toxicology 109 85-96. (https://doi. org/10.1111/j.1742-7843.2011.00688.x)

Ferrara D, Hallmark N, Scott H, Brown R, Mckinnell C, Mahood IK \& Sharpe RM 2006 Acute and long-term effects of in utero exposure of rats to di (n-butyl) phthalate on testicular germ cell development and proliferation. Endocrinology 147 5352-5362. (https://doi.org/10.1210/ en.2006-0527)

Frederick NN, Recklitis CJ, Blackmon JE \& Bober S 2016 Sexual dysfunction in young adult survivors of childhood cancer. Pediatric Blood and Cancer 63 1622-1628. (https://doi.org/10.1002/pbc.26041)

Freitas FEL, Cordeiro-mori F, Sasso-cerri E, Lucas SRR \& Miraglia SM 2002 Alterations of spermatogenesis in etoposide-treated rats: a stereological study. Interciencia 27 227-235.

Giudice MG, de Michele F, Poels J, Vermeulen M \& Wyns C 2017 Update on fertility restoration from prepubertal spermatogonial stem cells: how far are we from clinical practice? Stem Cell Research 21 171-177. (https://doi.org/10.1016/j.scr.2017.01.009)

Goossens E, Geens M, De Block G \& Tournaye H 2008 Spermatogonial survival in long-term human prepubertal xenografts. Fertility and Sterility 90 2019-2022. (https://doi.org/10.1016/j.fertnstert.2007.09.044)

Habert R, Lejeune H \& Saez JM 2001 Origin, differentiation and regulation of fetal and adult Leydig cells. Molecular and Cellular Endocrinology 179 47-74. (https://doi.org/10.1016/S0303-7207(01)00461-0)

Hasegawa H, Sung J-H \& Huh J-D 1997 Ginseng intestinal bacterial metabolite IH901 as a new anti-metastatic agent. Archives of Pharmacal Research 20 539-544. (https://doi.org/10.1007/BF02975208)

Hensle TW, Burbige KA, Shepard BR, Marboe CC, Blanc WA \& Wigger JH 1984 Chemotherapy and its effect on testicular morphology in children. Journal of Urology 131 1142-1144. (https://doi.org/10.1016/S00225347(17)50847-2)

Hermann BP, Sukhwani M, Winkler F, Pascarella JN, Peters KA, Sheng Y, Rodriguez M, Ezzelarab M, Dargo G, Peterson K et al. 2012 Spermatogonial stem cell transplantation into Rhesus testes regenerates spermatogenesis producing functional sperm. Cell Stem Cell $\mathbf{1 1}$ 715-726. (https://doi.org/10.1016/j.stem.2012.07.017)

Hou M, Chrysis D, Nurmio M, Parvinen M, Eksborg S, Söder O \& Jahnukainen K 2005 Doxorubicin induces apoptosis in germ line stem cells in the immature rat testis and amifostine cannot protect against this cytotoxicity. Cancer Research 65 9999-10005. (https://doi. org/10.1158/0008-5472.CAN-05-2004)

Hou M, Andersson M, Eksborg S, Söder O \& Jahnukainen K 2007 Xenotransplantation of testicular tissue into nude mice can be used for detecting leukemic cell contamination. Human Reproduction 22 1899-1906. (https://doi.org/10.1093/humrep/dem085)

Hudson MM 2010 Reproductive outcomes for survivors of childhood cancer. Obstetrics and Gynecology 116 1171-1183. (https://doi. org/10.1097/AOG.0b013e3181f87c4b)

Hyman LR \& Gilbert EF 1972 Testicular atrophy in a prepubescent male after cyclophosphamide therapy. Lancet 2 426-427. (https://doi. org/10.1016/S0140-6736(72)91820-X)

Ise T, Kishi K, Imashuku S, Tsukada M, Tsukimoto I, Tsujino G, Bessho F, Tanaka H, Miyazaki D \& Sakurai M 1986 Testicular histology and function following long-term chemotherapy of acute leukemia in children and outcome of the patients who received testicular biopsy. American Journal of Pediatric Hematology/Oncology 8 288-293. (https://doi.org/10.1097/00043426-198624000-00004) 
Jahnukainen K, Jahnukainen T, Salmi TT, Svechniko K, Eksborg S \& Söder O 2001 Amifostine protects against early but not late toxic effects of doxorubicin in infant rats. Cancer Research 61 6423-6427.

Jahnukainen K, Ehmcke J, Nurmio M \& Schlatt S 2012 Autologous ectopic grafting of cryopreserved testicular tissue preserves the fertility of prepubescent monkeys that receive sterilizing cytotoxic therapy. Cancer Research 72 5174-5178. (https://doi.org/10.1158/0008-5472.CAN-121317)

Kaatsch P 2010 Epidemiology of childhood cancer. Cancer Treatment Reviews 36 277-285. (https://doi.org/10.1016/j.ctrv.2010.02.003)

Kang JK, Lee YJ, No KO, Jung EY, Sung JH, Kim YB \& Nam SY 2002 Ginseng intestinal metabolite-I (GIM-I) reduces doxorubicin toxicity in the mouse testis. Reproductive Toxicology 16 291-298. (https://doi. org/10.1016/S0890-6238(02)00021-7)

Kelly J 2017 Childhood cancer in general practice: is it really that rare? InnovAiT: Education and Inspiration for General Practice 10 209-217. (https://doi.org/10.1177/1755738016689110)

Kelnar CJH 2002 Testicular changes during infantile 'quiescence' in the marmoset and their gonadotrophin dependence: a model for investigating susceptibility of the prepubertal human testis to cancer therapy? Human Reproduction 17 1367-1378. (https://doi.org/10.1093/ humrep/17.5.1367)

Kilcoyne KR, Smith LB, Atanassova N, Macpherson S, McKinnell C, van den Driesche S, Jobling MS, Chambers TJG, De Gendt K, Verhoeven G et al. 2014 Fetal programming of adult Leydig cell function by androgenic effects on stem/progenitor cells. PNAS 111 E1924-E1932. (https://doi org/10.1073/pnas.1320735111)

Kobayashi H, Urashima M, Hoshi Y, Uchiyama H, Fujisawa K, Akatsuka J, Maekawa K \& Hurusato M 1996 Testicular morphological changes in children with acute lymphoblastic leukemia following chemotherapy. Acta Paediatrica Japonica: Overseas Edition 38 640-643. (https://doi. org/10.1111/j.1442-200X.1996.tb03723.x)

Kuiri-Hänninen T, Sankilampi U \& Dunkel L 2014 Activation of the hypothalamic-pituitary-gonadal axis in infancy: minipuberty. Hormone Research in Paediatrics 82 73-80. (https://doi.org/10.1159/000362414)

Lee SH \& Shin CH 2013 Reduced male fertility in childhood cancer survivors. Annals of Pediatric Endocrinology and Metabolism 18 168-172. (https://doi.org/10.6065/apem.2013.18.4.168)

Lendon M, Hann IM, Palmer MK, Shalet SM \& Morris Jones PH 1979 Testicular histology after combination chemotherapy in childhood for acute lymphoblastic leukemia. Journal of Pediatric Surgery 14 401-402. (https://doi.org/10.1016/S0022-3468(79)80562-X)

Li X-Y, Zhang Y, Wang X-X, Jin C, Wang Y-Q, Sun T-C, Li J, Tang JX, Batool A, Deng S-L et al. 2017 Regulation of blood-testis barrier assembly in vivo by germ cells. FASEB Journal 32 1653-1664. (https:// doi.org/10.1096/fj.201700681R)

Lind M 2011 Principle of cytotoxic chemotherapy. Systemic Therapy 39 711-716. (https://doi.org/10.1016/j.mpmed.2007.10.003)

Lirdi LC, Stumpp T, Sasso-Cerri E \& Miraglia SM 2008 Amifostine protective effect on cisplatin-treated rat testis. Anatomical Record 291 797-808. (https://doi.org/10.1002/ar.20693)

Liu L, Blasco MA, Trimarchi JR \& Keefe DL 2002 An essential role for functional telomeres in mouse germ cells during fertilization and early development. Developmental Biology 249 74-84. (https://doi. org/10.1006/dbio.2002.0735)

Liu F, Li XL, Lin T, He DW, Wei GH, Liu JH \& Li LS 2012 The cyclophosphamide metabolite, acrolein, induces cytoskeletal changes and oxidative stress in Sertoli cells. Molecular Biology Reports 39 493-500. (https://doi.org/10.1007/s11033-011-0763-9)

Liu M, Hales BF \& Robaire B 2014 Effects of four chemotherapeutic agents, bleomycin, etoposide, cisplatin, and cyclophosphamide, on DNA damage and telomeres in a mouse spermatogonial cell line. Biology of Reproduction 90 1-10. (https://doi.org/10.1095/biolreprod.114.117754)

Liu Z, Nie Y, Zhang C, Cai Y, Wang Y, Lu H, Li Y, Cheng C, Qiu Z \& Sun $\mathbf{Q} 2016$ Generation of macaques with sperm derived from juvenile monkey testicular xenografts. Cell Research 26 139-142. (https://doi. org/10.1038/cr.2015.112)

Lopes F, Smith R, Nash S, Mitchell RT \& Spears N 2016 Irinotecan metabolite SN38 results in germ cell loss in the testis but not in the ovary of prepubertal mice. Molecular Human Reproduction 22 745-755. (https://doi.org/10.1093/molehr/gaw051)
Malhotra V \& Perry MC 2003 Classical chemotherapy: mechanisms, toxicities and the therapeutic window. Cancer Biology and Therapy 2 S2-S4. (https://doi.org/10.4161/cbt.372)

Marcon L, Zhang X, Hales BF, Nagano MC \& Robaire B 2010 Development of a short-term fluorescence-based assay to assess the toxicity of anticancer drugs on rat stem/progenitor spermatogonia in vitro. Biology of Reproduction 83 228-237. (https://doi.org/10.1095/ biolreprod.110.083568)

Masliukaite I, Hagen JM, Jahnukainen K, Stukenborg JB, Repping S, van der Veen F, van Wely M \& van Pelt AMM 2016 Establishing reference values for age-related spermatogonial quantity in prepubertal human testes: a systematic review and meta-analysis. Fertility and Sterility $\mathbf{1 0 6}$ 1652.e2-1657.e2. (https://doi.org/10.1016/j.fertnstert.2016.09.002)

Matus-Ridley M, Nicosia SV \& Meadows AT 1985 Gonadal effects of cancer therapy in boys. Cancer 55 2353-2363. (https://doi.org/10.1002/10970142(19850515)55:10<2353::AID-CNCR2820551010>3.0.CO;2-L)

Mayerhofer A 2013 Human testicular peritubular cells: more than meets the eye. Reproduction 145 R107-R116. (https://doi.org/10.1530/REP12-0497)

Miller KD, Siegel RL, Lin CC, Mariotto AB, Kramer JL, Rowland JH, Stein KD, Alteri R \& Jemal A 2016 Cancer treatment and survivorship statistics, 2016. CA: A Cancer Journal for Clinicians 66 271-289. (https:// doi.org/10.3322/caac.21349)

Mitchell RT, Cowan G, Morris KD, Anderson RA, Fraser HM, Mckenzie KJ, Wallace WHB, Kelnar CJH, Saunders PTK \& Sharpe RM 2008 Germ cell differentiation in the marmoset (Callithrix jacchus) during fetal and neonatal life closely parallels that in the human. Human Reproduction 23 2755-2765. (https://doi.org/10.1093/humrep/den295)

Mitchell RT, Saunders PTK, Childs AJ, Cassidy-Kojima C, Anderson RA, Wallace WHB, Kelnar CJH \& Sharpe RM 2010 Xenografting of human fetal testis tissue: a new approach to study fetal testis development and germ cell differentiation. Human Reproduction 25 2405-2414. (https:// doi.org/10.1093/humrep/deq183)

Mitchell RT, Nahata L \& Quinn GP 2017 Fertility preservation: don't forget the boys. BMJ 356 j495. (https://doi.org/10.1136/bmj.j495)

Moher D, Liberati A, Tetzlaff J \& Altman DG 2009 Preferred reporting items for systematic reviews and meta-analyses: the PRISMA statement. BMJ 339 b2535-b2535. (https://doi.org/10.1136/bmj.b2535)

Müller J \& Skakkebaek NE 1983 Quantification of germ cells and seminiferous tubules by stereological examination of testicles from 50 boys who suffered from sudden death. International Journal of Andrology 6 143-156. (https://doi.org/10.1111/j.1365-2605.1983.tb00333.x)

Müller J, Skakkebœk NE \& Hertz H 1985 Initiation of Spermatogenesis during Chemotherapy for Leukemia. Acta Paediatrica Scandinavica $\mathbf{7 4}$ 956-960. (https://doi.org/10.1111/j.1651-2227.1985.tb10064.x)

Müller J, Hertz H \& Skakkebœk NE 1988 Development of the seminiferous epithelium during and after treatment for acute lymphoblastic leukemia in childhood. Hormone Research in Paediatrics 30 115-120. (https:/doi/ org/10.1159/000181041)

Nambu A, Kumamoto Y \& Mikuma N 1995 Effects of anti-cancer agents on cultured rat Sertoli cells. Nihon Hinyokika Gakkai Zasshi: The Japanese Journal of Urology 86 1132-1136. (https://doi.org/10.5980/ jpnjurol1989.86.1132)

Nurmio M, Keros V, Lähteenmäki P, Salmi T, Kallajoki M \& Jahnukainen K 2009a Effect of childhood acute lymphoblastic leukemia therapy on spermatogonia populations and future fertility. Journal of Clinical Endocrinology and Metabolism 94 2119-2122. (https://doi.org/10.1210/ jc.2009-0060)

Nurmio M, Toppari J, Kallio J, Hou M, Söder O \& Jahnukainen K 2009b Functional in vitro model to examine cancer therapy cytotoxicity in maturing rat testis. Reproductive Toxicology 27 28-34. (https://doi. org/10.1016/j.reprotox.2008.10.004)

Nurmio M, Kallio J, Adam M, Mayerhofer A, Toppari J \& Jahnukainen K 2012 Peritubular myoid cells have a role in postnatal testicular growth. Spermatogensis 2 79-87. (https://doi.org/10.4161/spmg.20067)

Okada FK, Stumpp T \& Miraglia SM 2009 Carnitine reduces testicular damage in rats treated with etoposide in the prepubertal phase. Cell and Tissue Research 337 269-280. (https://doi.org/10.1007/s00441-0090801-2)

Ortiz RJ, Lizama C, Codelia VA \& Moreno RD 2009 A molecular evaluation of germ cell death induced by etoposide in pubertal rat testes. Molecular 
Human Reproduction 15 363-371. (https://doi.org/10.1093/molehr/ gap024)

Palmero S, Bottazzi C, Costa M, Leone M \& Fugassa E 2000 Metabolic effects of L-carnitine on prepubertal rat Sertoli cells. Hormone and Metabolic Research 32 87-90. (https://doi.org/10.1055/s-2007-978596)

Paniagua R \& Nistal M 1984 Morphological and histometric study of human spermatogonia from birth to the onset of puberty. Journal of Anatomy 139 535-552.

Parvinen L-M \& Parvinen M 1978 Biochemical studies of the rat seminiferous epithelial DNA and RNA syntheses and effects of adriamycin. Annales de Biologie Animale Biochimie Biophysique 18 585-594. (https://doi. org/10.1051/rnd:19780332)

Pennisi AJ, Grushkin CM \& Lieberman E 1975 Gonadal function in children with nephrosis treated with cyclophosphamide. Archives of Pediatrics and Adolescent Medicine 129 315-318. (https://doi.org/10.1001/ archpedi.1975.02120400027006)

Penso J, Lippe B, Ehrlich R, Smith FG \& Angeles L 1974 Testicular function in prepubertal and pubertal male patients treated with cyclophosphamide for nephrotic syndrome. Journal of Pediatrics 84 831-836. (https://doi. org/10.1016/S0022-3476(74)80758-4)

Petersen C \& Söder O 2006 The sertoli cell - a hormonal target and ' super ' nurse for germ cells that determines testicular size. Hormone Research 66 153-161. (https://doi.org/10.1159/000094142)

Picton HM, Wyns C, Anderson RA, Goossens E, Jahnukainen K, Kliesch S, Mitchell RT, Pennings G, Rives N, Tournaye H et al. 2015 A European perspective on testicular tissue cryopreservation for fertility preservation in prepubertal and adolescent boys. Human Reproduction 30 2463-2475. (https://doi.org/10.1093/humrep/dev190)

Poganitsch-Korhonen M, Masliukaite I, Nurmio M, Lähteenmäki PM, van Wely M, van Plet A, Jahnukainen K \& Stukenborg J 2017 Decreased spermatogonial quantity in prepubertal boys with leukaemia treated with alkylating agents. Leukemia 31 1460-1463. (https://doi.org/10.1038/ leu.2017.76)

Quigley C, Cowell C, Jimenez M, Burger H, Kirk J, Bergin M, Stevens M, Simpson J \& Silink M 1989 Testicular histology after combination chemotherapy in childhood for acute lymphoblastic leukemia. New England Journal of Medicine 321 143-151. (https://doi.org/10.1056/ NEJM198907203210303)

Rebourcet D, Shaughnessy PJO, Pitetti J, Monteiro A, Hara LO, Milne L, Tsai YT, Cruickshanks L, Riethmacher D, Guillou F et al. 2014 Sertoli cells control peritubular myoid cell fate and support adult Leydig cell development in the prepubertal testis. Development 141 2139-2149. (https://doi.org/10.1242/dev.107029)

Rey RA 1999 The prepubertal testis: a quiescent or a silently active organ? Histology and Histopathology 14 991-1000. (https://doi.org/10.14670/ $\mathrm{HH}-14.991)$

Rey RA, Campo SM, Bedecarras P, Nagle CA \& Chemes HE 1993 Is infancy a quiescent period of testicular development? Histological, morphometric, and functional study of the seminiferous tubules of the cebus monkey from birth to the end of puberty. Journal of Clinical Endocrinology and Metabolism 76 1325-1331. (https://doi.org/10.1210/ jcem.76.5.8496325)

Rivkees SA \& Crawford JD 1988 The relationship of gonadal activity and chemotherapy-induced gonadal damage. JAMA 259 2123-2125. (https://doi.org/10.1001/jama.1988.03720140043031)

Sadri-Arekani H, Akhondi M, van der Veen F, Reppng S \& van Pelt A 2011 In vitro propagation of human prepubertal spermatogonial stem cells. JAMA 305 2416-2418. (https://doi.org/10.1001/jama.2011.791)

Sato T, Katagiri K, Yokonishi T, Kubota Y, Inoue K, Ogonuki N, Matoba S, Ogura A \& Ogawa T 2011 In vitro production of fertile sperm from murine spermatogonial stem cell lines. Nature Communications 2 472-477. (https://doi.org/10.1038/ncomms1478)

Sayed-Ahmed MM 2010 Role of carnitine in cancer chemotherapyinduced multiple organ toxicity. Saudi Pharmaceutical Journal 18 195-206. (https://doi.org/10.1016/j.jsps.2010.07.008)

Shabani R, Ashtari K, Behnam B, Izadyar F, Asgari H, Asghari Jafarabadi M, Ashjari M, Asadi E \& Koruji M 2016 In vitro toxicity assay of cisplatin on mouse acute lymphoblastic leukaemia and spermatogonial stem cells. Andrologia 48 584-594. (https://doi.org/10.1111/and.12490)

Sharpe RM 2001 Hormones and testis development and the possible adverse effects of environmental chemicals. Toxicology Letters 120 221-232. (https://doi.org/10.1016/S0378-4274(01)00298-3)
Sharpe RM, McKinnell C, Kivlin C \& Fisher JS 2003 Proliferation and functional maturation of Sertoli cells, and their relevance to disorders of testis function in adulthood. Reproduction 125 769-784. (https://doi. org/10.1530/rep.0.1250769)

Smart E, Lopes F, Rice S, Nagy B, Anderson RA, Mitchell RT \& Spears N 2018 Chemotherapy drugs cyclophosphamide, cisplatin and doxorubicin induce germ cell loss in an in vitro model of the prepubertal testis. Scientific Reports 8 1-15. (https://doi.org/10.1038/s41598-017-17765-5)

Spencer CM \& Goa KL 1995 Amifostine. A review of its pharmacodynamic and pharmacokinetic properties, and therapeutic potential as a radioprotector and cytotoxic chemoprotector. Drugs 50 1001-1031. (https://doi.org/10.2165/00003495-199550060-00008)

Stanton PG 2016 Regulation of the blood-testis barrier. Seminars in Cell and Developmental Biology 59 166-173. (https://doi.org/10.1016/j. semcdb.2016.06.018)

Stukenborg J-B, Kjartansdóttir KR, Reda A, Colon E, Albersmeier JP \& Söder O 2014 Male germ cell development in humans. Hormone Research in Paediatrics 81 2-12. (https://doi.org/10.1159/000355599)

Stukenborg J-B, Jahnukainen K, Hutka M \& Mitchell RT 2018a Cancer treatment in childhood and testicular function: the role of the somatic environment. Endocrine Connections 7 R69-R87. (https://doi. org/10.1530/EC-17-0382)

Stukenborg J-B, Alves-Lopes JP, Kurek M, Albalushi H, Reda A, Keros V, Töhönen V, Bjarnason R, Romerius P, Sundin M et al. 2018b Spermatogonial quantity in human prepubertal testicular tissue collected for fertility preservation prior to potentially sterilizing therapy. Human Reproduction 33 1677-1683. (https://doi.org/10.1093/humrep/dey240)

Stumpp T, Sasso-Cerri E, Freymuller E \& Miraglia SM 2004 Apoptosis and testicular alterations in albino rats treated with etoposide during the prepubertal phase. Anatomical Record Part A: Discoveries in Molecular, Cellular, and Evolutionary Biology 279 611-622. (https://doi. org/10.1002/ar.a.20045)

Stumpp T, Freymüller E \& Miraglia SM 2006 Sertoli cell function in albino rats treated with etoposide during prepubertal phase. Histochemistry and Cell Biology 126 353-361. (https://doi.org/10.1007/s00418-006-0168-3)

Stumpp T, Freymuller E \& Miraglia SM 2008 Sertoli cell morphological alterations in albino rats treated with etoposide during prepubertal phase. Microscopy and Microanalysis 14 225-235. (https://doi.org/10.1017/ S1431927608080318)

Su D-M, Feng Y, Wang L, Wu Y-L, Ge RS \& Xue M 2018 Influence of fetal Leydig cells on the development of adult Leydig cell population in rats. Journal of Reproduction and Development 64 223-231. (https://doi. org/10.1262/jrd.2017-102)

Svechnikov K, Landreh L, Weisser J, Izzo G, Colón E, Svechnikov I \& Söder O 2010 Origin, development and regulation of human leydig cells. Hormone Research in Paediatrics 73 93-101. (https://doi. org/10.1159/000277141)

Svingen T \& Koopman P 2013 Building the mammalian testis: origins, differentiation, and assembly of the component cell populations. Genes and Development 27 2409-2426. (https://doi.org/10.1101/ gad.228080.113)

Sylvester SR \& Griswold MD 1994 The testicular iron shuttle: a 'nurse' function of the Sertoli cells. Journal of Andrology 15 381-385. (https:// doi.org/10.1002/j.1939-4640.1994.tb00468.x)

Teerds KJ \& Huhtaniemi IT 2015 Morphological and functional maturation of Leydig cells: from rodent models to primates. Human Reproduction Update 21 310-328. (https://doi.org/10.1093/humupd/dmv008)

Tremblay AR \& Delbes G 2018 In vitro study of doxorubicin-induced oxidative stress in spermatogonia and immature sertoli cells. Toxicology and Applied Pharmacology 348 32-42. (https://doi.org/10.1016/j. taap.2018.04.014)

Uderzo C, Locasciulli A, Marzorati R, Adamoli L, Di Natale B, Nizzoli G, Cazzaniga M \& Masera G 1984 Correlation of gonadal function with histology of testicular biopsies at treatment discontinuation in childhood acute leukemia. Medical and Pediatric Oncology 12 97-100. (https:// doi.org/10.1002/mpo.2950120207)

Van Saen D, Goossens E, Bourgain C, Ferster A \& Tournaye H 2011 Meiotic activity in orthotopic xenografts derived from human postpubertal testicular tissue. Human Reproduction 26 282-293. (https://doi. org/10.1093/humrep/deq321)

Van Saen D, Goossens E, Haentjens P, Baert Y \& Tournaye H 2013 Exogenous administration of recombinant human $\mathrm{FSH}$ does not improve germ cell 
survival in human prepubertal xenografts. Reproductive BioMedicine Online 26 286-298. (https://doi.org/10.1016/j.rbmo.2012.11.013)

Velez de la Calle JF, Soufir JC, Chodorge F, Boisseau C, Kercret H \& Jegou B 1988 Reproductive effects of the anti-cancer drug procarbazine in male rats at different ages. Journal of Reproduction and Fertility $\mathbf{8 4}$ 51-61. (https://doi.org/10.1530/jrf.0.0840051)

Velez de la Calle JF, de Queiroz F, Garnier DH, Kercret H, Folliot R \& Jegou B 1989 Reproductive effects of the anticancer drug cyclophosphamide in male rats at different ages. Archives of Andrology 22 251-263. (https:// doi.org/10.3109/01485018908986781)

Vendramini V, Sasso-Cerri E \& Miraglia SM 2010 Amifostine reduces the seminiferous epithelium damage in doxorubicin-treated prepubertal rats without improving the fertility status. Reproductive Biology and Endocrinology 8 3. (https://doi.org/10.1186/1477-7827-8-3)

Vendramini V, Robaire B \& Miraglia SM 2012 Amifostine-doxorubicin association causes long-term prepubertal spermatogonia DNA damage and early developmental arrest. Human Reproduction 27 2457-2466. (https://doi.org/10.1093/humrep/des159)

Vergouwen RPF, Huiskamp R, Bas R, Roepers-Gajadien H, Davids JA. \& de Rooij D 1993 Postnatal development of testiculr cell populations in mice. Journal of Reproduction and Fertility 99 479-485. (https://doi. org/10.1530/jrf.0.0990479)

Wallace WHB 2011 Oncofertility and preservation of reproductive capacity in children and young adults. Cancer 117 2301-2310. (https:// doi.org/10.1002/cncr.26045)

Wallace WHB, Shalet SM, Lendon M \& Morris Jones PH 1991 Male fertility in long-term survivors of childhood acute lymphoblastic leukaemia. International Journal of Andrology 14 312-319. (https://doi. org/10.1111/j.1365-2605.1991.tb01098.x)

Winther JF, Olsen JH, Wu H, Shyr Y, Mulvihill JJ, Stovall M, Nielsen A, Schmiegelow M \& Boice JD Jr 2012 Genetic disease in the children of danish survivors of childhood and adolescent cancer. Journal of Clinical Oncology 30 27-33. (https://doi.org/10.1200/JCO.2011.35.0504)

Wu X, Schmidt JA, Avarbock MR, Tobias JW, Carlson CA, Kolon TF, Ginsberg JP \& Brinster RL 2009 Prepubertal human spermatogonia and mouse gonocytes share conserved gene expression of germline stem cell regulatory molecules. PNAS 106 21672-21677. (https://doi. org/10.1073/pnas.0912432106)
Wyns C, Curaba M, Martinez-Madrid B, Van Langendonckt A, FrançoisXavier W \& Donnez J 2007 Spermatogonial survival after cryopreservation and short-term orthotopic immature human cryptorchid testicular tissue grafting to immunodeficient mice. Human Reproduction 22 1603-1611. (https://doi.org/10.1093/humrep/dem062)

Wyns C, Van Langendonckt A, Wese FX, Donnez J \& Curaba M 2008 Long-term spermatogonial survival in cryopreserved and xenografted immature human testicular tissue. Human Reproduction 23 2402-2414. (https://doi.org/10.1093/humrep/den272)

Wyns C, Curaba M, Vanabelle B, van Langendonckt A \& Donnez J 2010 Options for fertility preservation in prepubertal boys. Human Reproduction Update 16 312-328. (https://doi.org/10.1093/humupd/ dmp054)

Yoon JY, Park HJ, Chung JS, Hwang SH, Lee DO, Shim HY \& Park BK 2017 Gonadal and sexual dysfunction in childhood cancer survivors. Cancer Research and Treatment 49 1057-1064. (https://doi.org/10.4143/ crt.2016.197)

Zebrack B, Casillas J \& Nohr L 2004 Fertility issues for young adult survivors of childhood cancer. Psycho-Oncology 699 689-699. (https:// doi.org/10.1002/pon.784)

Zhang D, Yasuda T, Yu Y, Zheng P, Kawabata T, Ma Y \& Okada S 1996 Ginseng extract scavenges hydroxyl radical and protects unsaturated fatty acids from decomposition caused by iron-mediated lipid peroxidation. Free Radical Biology and Medicine 20 145-150. (https:// doi.org/10.1016/0891-5849(95)02020-9)

Zohni K, Zhang X, Tan SL, Chan P \& Nagano MC 2012 The efficiency of male fertility restoration is dependent on the recovery kinetics of spermatogonial stem cells after cytotoxic treatment with busulfan in mice. Human Reproduction 27 44-53. (https://doi.org/10.1093/humrep/ der357)

Received 30 April 2018

First decision 1 June 2018

Revised manuscript received 8 October 2018

Accepted 12 October 2018 